\title{
The Labor Market Effects of Offshoring by U.S. Multinational Firms: Evidence from Changes in Global Tax Policies*
}

\author{
Brian Kovak \\ Carnegie Mellon University \\ and NBER
}

\author{
Lindsay Oldenski \\ Georgetown University \\ and PIIE
}

\author{
Nicholas Sly ${ }^{\dagger}$ \\ Federal Reserve Bank \\ of Kansas City \\ and University of Oregon
}

June 2015

\begin{abstract}
Estimating the causal effect of offshoring on domestic employment is notoriously difficult because of the inherent simultaneity of domestic and foreign affiliate employment decisions. We use a model of endogenous offshoring to characterize this simultaneity and to derive an instrumental variables strategy allowing us to estimate the impact of offshore hiring on domestic employment. Our IV strategy exploits variation in offshoring costs across countries, industries, and time that results from the implementation of bilateral tax treaties, and uses Bureau of Economic Analysis (BEA) firm-level data for U.S. multinationals across two decades. We confirm that new treaties are unrelated to existing employment trends, and proceed to estimate the effects of offshoring on U.S. employment within multinational firms, industry-wide, and within local labor markets. We find that a 10 percent increase in foreign affiliate employment increases domestic U.S. employment for existing multinational firms by 1.4 percent, consistent with increased scale of production following a decline in global production costs. However, industry-wide U.S. employment increases by only one-third as much, as the opening of new offshore production facilities generates substitution for workers that had been hired domestically. We estimate slightly larger effects for local labor markets, suggesting there are possible spillovers across industries in the same location. Throughout the analysis, OLS estimates, which fail to account for the simultaneity of domestic and offshore employment, are more than 3 times larger than the preferred IV estimates. Overall, our results indicate that greater offshore activity raises net employment by U.S. firms.
\end{abstract}

Keywords: Offshoring, Employment, FDI, Incomplete Contracts JEL Classification: F16, F23, F66, J20, J30

${ }^{*}$ The statistical analysis of firm-level data on U.S. multinational companies was conducted at the Bureau of Economic Analysis, U.S. Department of Commerce under arrangements that maintain legal confidentiality requirements. The views expressed are those of the authors and do not reflect official positions of the U.S. Department of Commerce. The authors would like to thank William Zeile and Raymond Mataloni for assistance with the BEA data and Brian Cadena, Dave Donaldson, Andrew Goodman-Bacon, Ben Keys, Peter Morrow, Greg Wright, and seminar participants at American University, Colorado-Boulder, Dallas Fed, EITI, ETSG, FIU, GA Tech, GMU, Oregon, PIIE, Pitt, Purdue, Stanford, and the USITC for helpful discussions.

${ }^{\dagger}$ The views expressed herein are those of the authors and do not necessarily represent the views of the Federal Reserve Bank of Kansas City or Federal Reserve System. Nicholas Sly gratefully acknowledges financial support from the WE Upjohn Institute. 


\section{Introduction}

For more than a decade, the question of how offshoring affects domestic employment has been at the forefront of political and popular discussions of international economic policy. In spite of the salience of this question, there is little agreement among academic economists regarding the sign of offshoring's effects on domestic labor market outcomes, let alone the magnitude. ${ }^{1}$ Some of the disagreement in the academic literature potentially stems from differences in the definition of what activities constitute offshoring, but another more fundamental challenge likely plays a central role. Offshoring activity and domestic employment both reflect choices made by firms, making it extremely difficult to disentangle the causal relationships between the two phenomena. As an example, if a firm faces a positive demand shock for its output, it is likely that both domestic employment and employment at offshore affiliates will increase, yet this correlation teaches us little about the causal effects of offshoring on domestic employment.

To overcome this inherent simultaneity between domestic and offshore employment, we exploit declines in the costs of offshore activity that are exogenous to firm choices. In particular, we identify changes in the relative costs of offshore activity resulting from new bilateral tax treaties (BTTs). These treaties allow firms to avoid double-taxation of income from foreign affiliate activity, in which a lack of coordination between countries' taxing authorities results in the same income being taxed in two jurisdictions. BTTs resolve this problem and lower the effective tax rate on income from foreign affiliates in nearly all cases, hence lowering the overall cost of offshore activity. ${ }^{2}$ We leverage variation in the timing of treaties, the country mix of multinational firms' affiliates, and the incidence of double taxation across industries to infer the causal effect of BTT-induced changes in employment at the foreign affiliates of U.S. multinational firms on changes in U.S. domestic employment. Throughout our analysis, we take care to ensure the exogeneity of BTTs with respect

\footnotetext{
${ }^{1}$ For example, Desai, Foley, and Hines (2009) find a positive association between domestic labor market outcomes and offshoring activities of U.S. multinationals, while Muendler and Becker (2010) find negative effects for German multinational firms. Harrison and McMillan (2011) provide evidence from the U.S. that the association between offshore and domestic employment may depend on the type of offshoring activity. The destination of offshore activities may also alter the relationship between domestic and foreign employment; see Brainard and Riker (1997). Rather than positive or negative effects, several studies find null impacts of offshoring on domestic labor market outcomes; see Slaughter $(2000,2001)$.

${ }^{2}$ In 2014, the U.S. IRS and its counterparts in BTT partner countries fully eliminated double taxation in 94 percent of the cases brought before them under Mutual Agreement Procedure (MAP) provisions of BTTs. Partial relief was granted in 3 percent of the cases, whereas only 3 percent of case resolutions resulted in no relief for the taxpayer (ErnstandYoung 2015).
} 
to counterfactual employment outcomes, showing that new treaty implementation is uncorrelated with existing employment trends in the years just before the treaty.

We motivate our empirical approach using the incomplete contracts model of multinational firms developed by Antràs and Helpman (2004), which demonstrates the simultaneity of employment decisions at the domestic parent and its foreign affiliates. ${ }^{3}$ From the model, we derive a panel difference-in-differences estimation strategy, with changes in effective tax rates serving as an instrument for offshore employment. Note that BTTs only influence these costs for integrated multinational firms, as opposed to those purchasing inputs at arms length. Hence, we use data from the Bureau of Economic Analysis (BEA) Surveys of U.S. Direct Investment Abroad, which include only integrated multinational firms. This approach allows us to measure the effects of BTTs on affiliate employment, and subsequently the effects of affiliate employment growth on employment at domestic parent firms.

As expected, we find substantial positive effects of BTTs on offshore employment levels for affiliates in treaty countries. Also consistent with expectations, these effects are restricted to affiliates in industries using relatively high shares of differentiated inputs, based on the Rauch (1999) classification. The incidence of double-taxation in the absence of a treaty is much higher in these industries, because taxing authorities have more difficulty allocating the location of earned economic income when differentiated inputs are used intensively in production (Blonigen, Oldenski, and Sly 2014). Hence BTTs lower effective tax rates on foreign affiliate activity much more in high input differentiation industries than in other industries. These results imply that BTTs influence foreign affiliate employment by lowering effective tax rates in a way that allows us to identify the causal effect of changes in offshore employment on domestic employment.

We find economically modest but statistically significant positive effects of offshoring on domestic employment at multinational parent firms. A 10 percent increase in affiliate employment is associated with a 1.38 percent increase in employment at the U.S. parent firm. These IV estimates are in contrast to the OLS results, which are more than three times larger. This sharp difference demonstrates the quantitative importance of addressing the endogeneity of offshore employment to unobserved determinants of domestic employment.

\footnotetext{
${ }^{3}$ See Feenstra and Hanson (2005) and Defever and Toubal (2013) for empirical support of the property rights/incomplete contracts theory of multinational firms.
} 
The Antràs and Helpman (2004) framework and empirical evidence in Harrison and McMillan (2011) make clear that the relationship between foreign affiliate activity and domestic employment differs across firms with various organizational forms or adjusting on different margins. Consistent with the theory, we find positive effects for continuing multinational firms that expand existing affiliate employment along the intensive margin and hire more workers domestically to complement the larger number of offshore workers. However, the model predicts that multinational firms adjusting on the extensive margin by opening new affiliates experience smaller positive or possibly negative effects of increased offshore activity, as the new offshore facilities substitute for activities that had previously been performed by workers in the U.S. Our results confirm this prediction as well; when restricting the sample to firms that open new affiliates in treaty countries following a BTT, the effect on domestic employment is cut in half.

We also use County Business Patterns data to study employment outcomes for overall national industries and local labor markets. The industry perspective allows us to capture two margins that are absent in the analysis of multinational firms alone. First, the changes in employment at multinational parents may be partly offset by equilibrium employment adjustment at other domestic firms in the industry. Second, declining costs of offshore activity will likely motivate some firms to become multinational firms by opening new affiliates. The model predicts that this behavior will lower domestic employment if the activities of these new affiliates substitute for activity that had previously been completed in the U.S. Both margins predict smaller effects at the industry level than at the multinational parent level, and this is exactly what we find. Offshoring's effect on overall industry employment is only one third as large as the effect on multinational parent employment.

The local labor market analysis adds another perspective on the employment consequences of offshoring by including potential employment spillovers across industries at the metropolitan area level. We generate a local measure of offshoring exposure as a weighted average of industrylevel foreign affiliate employment, with weights reflecting the market's initial industry mix, using a procedure similar to Topalova (2010), Autor, Dorn, and Hanson (2013), and Kovak (2013). As before, we instrument for observed affiliate employment using BTTs. The metro-area estimates are larger in magnitude than the industry results, consistent with the presence of cross-industry spillovers at the local level. 
Together, these results suggest that the net effect of increased activity at offshore affiliates of U.S. multinational corporations is to raise domestic employment for multinational parent firms and at the industry and local labor market levels. Our primary contribution is to provide a theoretically motivated policy instrument for offshore employment. The results make clear the quantitative importance of addressing the simultaneity of domestic and offshore employment. For all of our analyses, the IV estimates are far smaller than the associated OLS estimates, consistent with the theoretical prediction of upward bias in OLS measures of the effect of offshoring on domestic employment.

Muendler and Becker (2010) take an alternative approach to our IV strategy and estimate German multinational firms' cost functions based on cross-country differences in industry wages, explicitly accounting for firm-specific wage premia and the selection of multiple affiliates into various locations. ${ }^{4}$ They find evidence that home and foreign employment are substitutes both at the the intensive margin (within existing multinational firms) and the extensive margin (as firms open new offshore affiliates). Yet, as they note, their cross-wage substitution elasticity estimates appropriately hold constant the output of the multinational firm. In our framework, the key mechanism driving the positive relationship between domestic and offshore affiliate employment is that firms may expand output as offshoring costs fall and thus increase local hiring. Hence, our positive estimates at the intensive margin are consistent with foreign and domestic employment being substitutes, as demonstrated by Muendler and Becker (2010), since our estimates reflect a combination of substitution and scale effects following a reduction in offshoring costs.

Other work has documented that the relationship between offshore and domestic employment varies according to the affiliate country (Brainard and Riker 1997) and the type of offshoring activity (Harrison and McMillan 2011). By examining outcomes at different levels of aggregation, we are also able to capture heterogeneity in the effects of offshoring across firms with different organizational forms and different margins of adjustment. In all cases, our results confirm the theoretical predictions for the relative size of the effects for various subsamples of firms. These

\footnotetext{
${ }^{4}$ We also account for the presence of multiple affiliates, relying on location-specific time variation in offshoring costs driven by bilateral tax treaties in individual countries. Since we do not rely on wage differences for identification, the wage-based endogenous sample selection problem that Muendler and Becker (2010) overcome does not directly apply in our context. Wage differences across locations would only confound our analysis if they induced differential employment trends that were correlated with BTT introduction. We rule out this pattern by observing pre-treaty employment trends.
} 
findings support the notion that there is not a single effect of increased offshore activity on domestic employment, but that the effects vary depending on the circumstances.

This observation has important implications for relating our findings to others in the broader literature on the effects of increased imports. For example, our results may seem to be at odds with Autor, Dorn, and Hanson (2013), Hummels et al. (2014), and other related papers finding negative effects of total imports on labor market outcomes. It is important to emphasize that there is no contradiction here because of a sharp difference in the scope of the analysis. Total imports include final goods, inputs purchased abroad at arms-length, and inputs purchased from foreign affiliates of domestic multinationals. Each of these trade flows is likely to have a different effect on domestic labor market outcomes and is subject to different policy interventions, meaning that there is value in carefully measuring the effects of each type of international economic activity. We focus on the effects of increased employment at foreign affiliates of U.S. multinational firms both to take advantage of a compelling policy-based identification strategy and because the potential effects of offshoring by multinational firms have been the topic of much attention in political debates and the popular press, distinct from discussions of trade more broadly. Moreover, the U.S. Census Bureau reports that upwards of 40 percent of U.S. imports are between related parties, while Slaughter (2009) provides evidence that multinational enterprises account for approximately 20 percent of total labor usage in the U.S. Hence, the type of offshoring we consider here is of firstorder importance to U.S. labor market outcomes.

Although we find modest positive effects of offshoring on overall employment, there may be substantial changes in the underlying task composition of employment. Ottaviano, Peri, and Wright (2013) examine the impact of offshoring and immigration on American employment across different job tasks. Becker, Ekholm, and Muendler (2013) find that offshoring is associated with shifts in the task composition within German MNEs, as well as a shift in labor usage across worker skill levels. Other analyses focus on the role of offshoring in driving observed trends in job polarization in the US and Europe; see Goos and Manning (2007), Goos, Manning, and Salomons (2009), and Oldenski (2014). We view our analysis as complementary in that we focus on the impact of offshoring on overall employment levels, and abstract from the composition of job tasks as offshoring costs fall.

Our focus on the domestic employment consequences of offshoring activity parallels analyses that examine alternative domestic labor market outcomes such as wages, wage inequality or the 
skill composition of local labor demand. Similar to the literature on employment levels, there is little agreement on the consequences of offshoring for these other outcomes. Slaughter (2000) finds no evidence that greater offshoring by U.S. multinationals has affected the relative demand for skilled labor, while Head and Ries (2002) find that offshoring by Japanese firms to low-income countries raises the relative demand for skills domestically. Feenstra and Hanson (1999) estimate that approximately 15 percent of the rise in relative non-production wages throughout the 1980s is attributable to offshoring activities. Olney (2012) finds that offshoring and immigration flows

have significant, though differing, impacts on the relative wages of American workers. See also the survey of this literature in Feenstra and Hanson (2003).

The following section describes the model of offshoring within multinational firms, from which we derive our empirical strategy. Section 3 describes our empirical approach to measuring the employment effects of offshoring on multinational parent firms, industries, and local labor markets. Section 4 describes the BEA data on multinational firm employment and the County Business Patterns data we use to measure employment by industry and local labor market. Our empirical results appear in Section 5, and Section 6 concludes.

\section{A Model of Offshoring Activities and Hiring}

In this section we adopt a model of offshoring activities from Antràs and Helpman (2004), and use it to derive simultaneous domestic and offshore hiring decisions. When then use the model to characterize the dependence of employment decisions on exogenous costs of foreign affiliate activity, and derive an empirical strategy to estimate the impact of changes in these costs on US employment outcomes.

\section{$2.1 \quad$ Fundamentals}

The world economy consists of $D+1$ countries, with one country being located in the North and $D$ countries located in the South. Consumers in each country are laborers who all have identical quasilinear preferences over a homogeneous good, $x_{t 0}$ and a series composite goods across industries, $X_{t i}$, which are given by

$$
U_{t}=x_{t 0}+\frac{1}{\mu} \sum_{i=1}^{I} X_{t i}^{\mu} \quad, \quad 0<\mu<1
$$


where consumers exhibit preferences with a constant elasticity of substitution over unique varieties, $h$, among the total set of varieties available in the same industry, $H_{t i}$, in each period, $t$, given by

$$
X_{t i}=\left[\int_{h \in H_{t i}} x_{t i}(h)^{\alpha_{i}} d h\right]^{1 / \alpha_{i}} \quad, \quad 0<\alpha_{i}<1
$$

It follows that, within each period, monopolistically competitive firms each producing a unique variety, $h$, face an inverse demand function given by $p_{t i}(h)=X_{t i}^{\mu-\alpha_{i}} x_{t i}(h)^{\alpha_{i}-1}$.

Labor is the only factor of production, with a perfectly elastic supply in all countries, albeit with different wages. Let $\omega^{N}$ be the wage in the North and $\omega_{d}^{S}$ be the wage in each Southern country with $\omega^{N}>\omega_{d}^{S}$. Workers are hired by firms to perform either general labor services $s$ or to generate components used in assembly $m$. Each worker can produce a single unit of general labor services or components, and final goods producers combine labor services and components according to

$$
x_{t i}(h)=\theta(h)\left[\frac{s_{t}(h)}{\eta_{i}}\right]^{\eta_{i}}\left[\frac{m_{d t}(h)}{1-\eta_{i}}\right]^{1-\eta_{i}},
$$

where $\theta(h)$ is a firm-level productivity parameter (i.e., firm-level TFP). We assume that general labor services, $s_{t}(h)$, are performed in the North while components can be manufactured in the North, or in any Southern country, indexed by $d .{ }^{5}$ Regardless of where they are produced, components are firm-specific and are not compatible with alternative varieties of the final good. ${ }^{6}$

\subsection{Offshoring}

Although final good producers in the North may source components from foreign affiliates in the South, there are two frictions that inhibit offshore production. First, offshoring firms potentially face double-taxation, as tax authorities in each country misattribute the location of earned income by multinational firms, often leading to taxes levied in both jurisdictions upon the same income.

\footnotetext{
${ }^{5}$ For simplicity, we assume that domestic and offshore labor inputs are perfect substitutes in component production. Muendler and Becker (2010) find that they are, in fact, substitutes in the German context, though they are imperfect substitutes.

${ }^{6}$ For the sake of exposition, we begin with two inputs into final good production, but note that the production technology in equation (3) is flexible enough that we could easily incorporate several types of inputs that may be sourced across multiple countries, and the qualitative insights of the model would be maintained. In our empirical analysis we account for the hiring of workers global by multinational firm across multiple offshore destinations when estimating the impact on domestic employment.
} 
Hence, multinational firms may realize relatively higher effective tax rates than firms that source components domestically or at arms-length. Second, multinational firms cannot write complete contracts with their supplier, so that the sourcing of components from abroad is subject to a hold-up problem.

We denonte $\tau_{d t i}$ as the relatively higher tax rate paid by firms in industry $i$ that offshore component manufacture to an affiliate in country $d$ in the South during period $t$. We model $\tau_{d t i} \geq 1$ such that the the hiring of $\tau_{d t i}$ workers abroad yields one unit of components for production. Relevant to our empirical approach, it is important to recognize that the incidence of double taxation upon multinational firms may vary across countries, $d$, and over time, $t$, as the status of bilateral tax treaties between countries varies over time. Moreover, we recognize that the mis-application of tax rules can vary substantially according to the specifics of the production process across industries. For industries that require highly differentiated or intangible inputs in the production of final goods, it can be difficult to assign the location of value added or where income is earned. On the other hand, within industries that use primarily homogeneous inputs such as corn, wheat, or steel, it is more straightforward to assign appropriate transfer prices and therefore levy appropriate taxes across jurisdictions. Hence, we allow the effective tax rate, $\tau_{d t i}$, to also vary by industry.

The second friction to offshoring activity is the inability to write complete contracts with suppliers over the delivery of specialized inputs. The incomplete contracting environment in the global economy follows Antràs and Helpman (2004). Although firms cannot write enforceable contracts, a parent firm can integrate with its offshore supplier by purchasing the residual rights over its activities. Otherwise, the residual rights can be retained by the supplier, so that it interacts at arms-length with the final good producer in the North. Whether the parent and its suppliers integrate or operate at arms-length, the parent engages in ex post bargaining vìs-a-vìs each of its offshore affiliates over the surplus generated during production. We assume that the parent company receives a fraction $\beta$ of the surplus generated during production, while the remaining fraction goes to the individual supplier.

Acquiring the residual rights over an affiliate's activities allows the parent firm to seize the components generated by the supplier, however it cannot use them as effectively following seizure as when provided by the supplier voluntarily. ${ }^{7}$ The ability to recover assets following seizure depends

\footnotetext{
${ }^{7}$ The possibility that the parent firm may seize any components held by a supplier limits its incentive to invest in
} 
on the institutional quality of the legal system in each location $d$. To be specific, the parent company of a multinational firm loses $\left(1-\delta_{d}\right)<1$ of total final good production if is chooses to seize assets from an offshore affiliate in location $d$, rather than compensating the supplier for them.

By purchasing the residual rights over the assets of an offshore affiliate, the outside option of a parent company $h$ during negotiations is to seize the components manufactured by the supplier, thereby receiving a fraction of revenue equal to $\delta_{d}^{\alpha_{i}}$ of the revenue that would be generated by fulfilling the terms of the contract. Thus, the surplus generated during production when the parent compensates the supplier is the fraction $\left(1-\delta_{d}^{\alpha_{i}}\right)$ of total revenue. It follows that the problem parent firm $h$ in the North solves is to make hiring decisions, $s_{t}(h)$, in order to maximize its share of total surplus, given its outside option of seizing components fabricated by its foreign affiliate:

$$
\max _{s_{t}(h)}\left[\delta_{d}^{\alpha_{i}}+\beta\left(1-\delta_{d}^{\alpha_{i}}\right)\right] r_{t i}(h)-w^{N} s_{t}(h)
$$

where the revenue is $r_{t i}(h)=\theta(h)^{\alpha} X^{\mu-\alpha}\left[\frac{s_{t}(h)}{\eta_{i}}\right]^{\alpha \eta_{i}}\left[\frac{m_{d t}(h)}{1-\eta_{i}}\right]^{\alpha\left(1-\eta_{i}\right)}$. The corresponding problem for the component supplier in location $d$ in the South, during period $t$ is

$$
\max _{m_{d t}(h)}(1-\beta)\left(1-\delta_{d}^{\alpha_{i}}\right) r_{t i}(h)-\tau_{d t i} \omega_{d}^{S} m_{d t}(h)
$$

where the term $\tau_{d t i} \geq 1$ reflects the fact that using labor in the South to produce components may subject the multinational firm to the incidence of double-taxation.

\subsection{Labor Demand Within Multinational Firms}

We are now in a position to derive the simultaneous choices of local and offshore labor demand for multinational firms and to characterize our empirical strategy for circumventing this simultaneity when estimating the effect of offshore hiring on local employment outcomes. Note that this section focuses on the hiring decisions within existing multinational firms, and thus is concerned with how local employment responds to changes in offshoring costs at the intensive margin. The next section focuses the employment effects of changes in offshoring costs at the extensive margin, as firms may respond by changing the location/mode by which they source components.

production activities; yet the fact that the parent firm cannot use components as effectively without compensating the supplier curbs this hold-up problem so that the supplier is still incentivized to invest in some production ex ante. 
Solving the problem in (5) for an offshore affiliate in location $d$ that produces components for a firm producing variety $h \in H_{t i}$ yields optimal offshore hiring decisions, $m_{d t}(h)$, that are the best response to parent hiring decisions $s_{t}(h)$ during period $t$, which (after taking logs) are given by

$$
\begin{aligned}
\ln m_{d t}(h)=\ln (1- & \left.\eta_{i}\right)+\frac{\alpha_{i}\left[\ln \theta(h)-\eta_{i} \ln \eta_{i}\right]+\ln \left(1-\delta_{d}^{\alpha_{i}}\right)+\ln (1-\beta)+\ln \alpha_{i}-\ln \omega_{d}^{S}}{1-\alpha_{i}\left(1-\eta_{i}\right)}+ \\
& -\frac{\alpha_{i}-\mu}{1-\alpha_{i}\left(\eta_{i}-1\right)} \ln X_{t i}+\frac{\alpha_{i} \eta_{i}}{1-\alpha_{i}\left(1-\eta_{i}\right)} \ln s_{t}(h)-\frac{1}{1-\alpha_{i}\left(1-\eta_{i}\right)} \ln \tau_{d t i}
\end{aligned}
$$

The terms on the first line of (6) are firm, industry and destination specific parameters. We collapse these to a singe firm $\times$ industry $\times$ destination fixed effect, $\varphi_{h d i}$. The first term on the last line of (6) is industry by time specific, which is captured by a single industry $\times$ time fixed effect $\phi_{t i}$. Finally, in the last line we see that the demand for labor at the offshore affiliate depends on endogenous choices of general labor services the the parent firm in the North, $s_{t}(h)$, and the tax incidence, $\tau_{d t i}$, which each vary across time. For expositional purposes, we can rewrite (6) as

$$
\ln m_{d t}(h)=\varphi_{h d i}+\phi_{t i}+\gamma_{1} \ln s_{t}(h)-\gamma_{2} \ln \tau_{d t i}
$$

where $\gamma_{1} \equiv \frac{\alpha_{i} \eta_{i}}{1-\alpha_{i}\left(1-\eta_{i}\right)}$ and $\gamma_{2} \equiv \frac{1}{1-\alpha_{i}\left(1-\eta_{i}\right)}$.

Similarly, we can solve the problem in (4) to derive the hiring decisions of the parent company in the North that are a best response to offshore employment decisions, which yields

$$
\begin{array}{r}
\ln s_{t}(h)=\ln \eta_{i}+\frac{\ln \left[\delta_{d}^{\alpha_{i}}+\beta\left(1-\delta_{d}^{\alpha_{i}}\right)\right]+\ln \alpha_{i}-\ln \omega_{d}^{S}+\alpha_{i}\left[\ln \theta(h)-\left(1-\eta_{i}\right) \ln \left(1-\eta_{i}\right)\right]}{1-\alpha_{i} \eta_{i}} \\
-\frac{\alpha_{i}-\mu}{1-\alpha_{i} \eta_{i}} \ln X_{t i}+\frac{\alpha_{i}\left(1-\eta_{i}\right)}{1-\alpha_{i} \eta_{i}} \ln m_{d t}(h) .
\end{array}
$$

As before, the terms on the first line of (8) collapse into a firm $\times$ industry $\times$ destination fixed effect, $\psi_{h d i}$, while the first term on the second line is an industry $\times$ time fixed effect, $\vartheta_{t i}$. Rewriting (8) we obtain

$$
\ln s_{t}(h)=\psi_{h d i}+\vartheta_{t i}+\gamma_{1}^{\prime} \ln m_{d t}(h)
$$

where $\gamma_{1}^{\prime} \equiv \frac{\alpha_{i}\left(1-\eta_{i}\right)}{1-\alpha_{i} \eta_{i}}$ is the change in local hiring by multinational enterprises that results from a change in offshore employment. 


\subsection{Discussion}

The first thing to note from the system of equations in (7) and (9) is that the observed relationship between $s_{t}(h)$ and $m_{d t}(h)$ will yield a biased estimate of the parameter of interest, $\gamma_{1}^{\prime}$. Because domestic and offshore affiliate hiring are simultaneously determined, and since $\gamma_{1}>0$, the observed relationship will be biased upward ${ }^{8}$ Thus, we expect OLS estimates of the relationship between domestic and offshore affiliate employment to overstate the true effect.

However, equations (7) and (9) also provide a solution to the simultaneity problem. Hiring decisions of the parent firm in the North, $s_{t}(h)$, do not depend explicitly on the incidence of double-taxation from offshoring activities, $\tau_{d t i}$, but only implicitly through its effect on offshore hiring decisions $m_{d t}(h)$. This exclusion of offshoring costs from the hiring decisions in the North allows us to instrument for offshore hiring decisions using variation in $\tau_{d t i}$. We will generate predicted values of offshore employment from estimating (7), exploiting variation in $\tau_{d t i}$ that arises due to the exogenous signing of bilateral tax treaties, and subsequently use these predicted values as instruments when estimating domestic employment outcomes in (9). ${ }^{9}$

Our parameter of interest is $\gamma_{1}^{\prime}=\frac{\alpha_{i}\left(1-\eta_{i}\right)}{1-\alpha_{i} \eta_{i}}$, which is strictly positive. Hence, the model predicts that increases in hiring within offshore affiliates positively impacts hiring by parent companies in the North. Intuitively, greater amounts of component production by the affiliate are complemented by greater production of general labor services in the North, so that employment at the parent should also rise. ${ }^{10}$ This positive association at the intensive margin between local and offshore employment that occurs within multinational firms is similar to the productivity effect derived in Grossman and Rossi-Hansberg (2008) and evidenced in Olney (2012), where a reduction in offshoring costs raises the return to hiring complementary inputs, and thereby partially improves domestic labor market outcomes. ${ }^{11}$ The model also makes specific predictions on the magnitude of the effect of offshore

\footnotetext{
${ }^{8}$ The sign of additive simultaneity bias is given by the sign of $\gamma_{1}$ as long as the condition $\gamma_{1} \gamma_{1}^{\prime}<1$ is satisfied. This condition is necessary for the existence of equilibrium, and is satisfied in our context, since $0<\alpha_{i}, \eta_{i}<1$.

${ }^{9}$ Using predicted values as instruments, rather than as part of a two-stage least squares procedure, is necessary because of nonlinearity in aggregating across siblings for parent firms with multiple affiliates. See Section 3.3 for details.

${ }^{10}$ The strategic complementarity between parent and affiliate employment results from the requirement that monopolistically competitive firms operate on the elastic portion of the demand curve, i.e. that $0<\alpha<1$. A decline in output price driven by a decline in offshore costs more than proportionally increases output quantity, increasing the rents to be split between the parent and affiliate.

${ }^{11}$ The increase in demand for labor as total production costs fall is often generally refer to as a 'scale' effect outside the international trade literature.
} 
hiring on local employment; $\gamma_{1}^{\prime} \equiv \frac{\alpha_{i}\left(1-\eta_{i}\right)}{1-\alpha_{i} \eta_{i}}$ is strictly bounded between zero and unity. Hence the model predicts that there is less than an one-for-one increase in local hiring by multinational firms as offshore employment rises.

\subsection{Industry Labor Demand}

Firms have several options for how and where to source components other than from offshore affiliates. A firm may respond to changes in offshoring costs by altering its global sourcing strategy. Thus, when considering the industry-wide response of domestic employment to changes in the cost to source specialized inputs from foreign affiliates, we must take into account firms that use alternative sourcing modes and those that change their offshoring strategy. Here, we derive total industry-level employment and characterize an empirical strategy to estimate its response to changes in the cost of offshore activities.

Total industry employment in the North includes hiring for general labor services $s_{t}(\cdot)$ across all firms, as well as any labor used to manufacture components $m_{t}(\cdot)$ domestically, either in-house or at arms-length. Let, $O_{t i}$ be the set of firms in industry $i$ that choose to offshore component production to an affiliate in the in the South during period $t$, while $A_{t i}$ is the set of firms that source component production from an arms-length supplier in the South. Likewise let $I_{t i}$ denote the set of non-multinational firms that hire local workers in the North to manufacture components in-house, while $U_{t i}$ is the set of firms that source production of components from local arms-length suppliers in the North. Summing across all firm organizational types, total employment for industry $i$ in the North is given by

$$
\begin{aligned}
L_{t i}^{N}= & \int_{h \in O_{t i} \subset H_{t i}} s_{t}(h) d h+\int_{h \in A_{t i} \subset H_{t i}} \\
& s_{t}(h) d h \\
& +\int_{h \in I_{t i} \subset H_{t i}}\left[m_{d t}(h)+s_{t}(h)\right] d h+\int_{h \in U_{t i} \subset H_{t i}}\left[m_{d t}(h)+s_{t}(h)\right] d h .
\end{aligned}
$$

Equation (10) is the basis of our empirical strategy when estimating the effect of offshoring activity on industry-level employment. There are several features that warrant further discussion. First, in addition to the simultaneously determined employment levels within firms, total industry employment depends on the prevalence of each endogenously determined organizational structure 
across firms. Each firm chooses to source components in a manner that maximizes its expected payoff in anticipation of hiring decisions. Formally, let $F_{i}^{k}$ be the industry-specific fixed costs associated with adopting organization structure $k \in\left\{O_{t i}, A_{t i}, I_{t i}, U_{t i}\right\}$, and let $\Pi_{t i}^{k}(h)$ be the payoff to the parent firm producing variety $h$ in industry $i$ when it chooses to source components according to organizational structure $k$. The problem of the parent when choosing how and where to source components is

$$
\max _{k \in\left\{O_{t i}, A_{t i}, I_{t i}, U_{t i}\right\}} \Pi_{t i}^{k}(h)-F_{i}^{k} .
$$

Importantly, the incidence of double-taxation, $\tau_{d t i}$, impacts firm organizational choices, and thus local employment outcomes, only through its anticipated effect on foreign hiring decisions; i.e., $\tau_{d t i}$ does not enter firms' organization decisions explicitly, but implicitly through its effect on endogenously determined levels of $m_{d t}(h)$. This fact ensures that changes in effective tax rates due the signing of a new BTT are a valid instrument when estimating the industry-level employment consequences of offshoring activity. ${ }^{12}$

We characterize the change in industry-wide labor demand following a reduction in the effective tax on offshore activities by differentiating (10) with respect to $\tau_{d t i}$. Let $O_{t i}^{\prime}, A_{t i}^{\prime}, I_{t i}^{\prime}$, \& $U_{t i}^{\prime}$ be the sets of firms that choose the respective organizational type following a reduction in $\tau_{d t i}$. Then, the consequences of a reduction in offshoring $\operatorname{costs}\left(\partial \tau_{d t i}<0\right)$ for industry-level employment are characterized by

$$
\frac{\partial L_{t i}^{N}}{\partial \tau_{d t i}}=\int_{h \in O_{t i}} \frac{\partial s_{t}(h)}{\partial m_{t}(h)} \frac{\partial m_{t}(h)}{\partial \tau_{d t i}} d h-\int_{h \in O_{t i}^{\prime} \backslash O_{t i}} m_{d t}(h) d h .
$$

The first term in equation (11) corresponds to the change in employment within existing MNEs that results from a change in offshoring costs. As discussed above, at this intensive margin, existing multinational firms respond to a reduction in offshoring costs $\tau_{d t i}$ by increasing employment locally. Similar to the well-known productivity effect in Grossman and Rossi-Hansberg (2008), a fall in offshoring costs within existing MNEs increases their output, which is a boon to local labor markets. Formally, this is seen from equation (9) that $-\frac{\partial s_{t}(\cdot)}{\partial m_{t}(\cdot)} \frac{\partial m_{t}(\cdot)}{\partial \tau_{d t i}}=\frac{\alpha_{i}\left(1-\eta_{i}\right)}{1-\alpha_{i} \eta_{i}}>0$.

\footnotetext{
${ }^{12}$ An alternative to IV estimation of industry level employment in (10) is to impose structural assumptions about the ranking of fixed costs across industries and the distribution of firm-level productivities, and estimate the propensity of firms to adopt each respective organizational type. See Antràs and Helpman (2004) for a discussion of the prevalence of organizational types within industries with such assumptions imposed, and evidence in Defever and Toubal (2013) that is consistent with their predictions. Our IV approach has the benefit that is it does not require that we impose assumptions about firm organizational behavior within or across industries.
} 
The second term on the right-hand-side of (11) corresponds to effects at the extensive margin. Recall that a reduction in $\tau_{d t i}$ lowers the cost of sourcing inputs only for offshoring firms with foreign affiliates. As a result, some firms may begin to substitute offshore labor within new affiliates for workers that used to be hired locally. This adjustment by new multinational firms at the extensive margin has negative consequences for local industry-level employment. Specifically, these are the firms that are offshoring MNEs ex post, but were not engaged in offshoring ex ante; i.e., firms producing varieties $h \in O_{t i}^{\prime} \backslash O_{t i} \cdot{ }^{13}$

Given the positive effects of a reduction in offshoring costs at the intensive margin within existing multinational firms, and the negative effects at the extensive margin as some firms substitute offshore facilities for local component production, it is then an empirical question how a reduction in offshoring costs influences total local employment at the industry-level. The US Census Bureau reports that a sizable proportion of all US imports are between related parties, so that a reduction in the incidence of double-taxation for within-firm trading activity may have a substantial quantitative effect on firm-level hiring. Given the evidence in Slaughter (2009) that US MNEs account for upwards of $20 \%$ of total private sector employment, increases in hiring within these firms may substantially boost total employment at aggregate levels. On the other hand, evidence in Blonigen, Oldenski, and Sly (2014) and Davies, Norback, and Tekin-Koru (2009) show that the signing of a new BTT has a significant impact on the propensity of MNEs to open new affiliates in treaty countries. Evidence in Muendler and Becker (2010) and Monarch, Park, and Sivadasan (2014) suggest that such domestic plant closures due to the opening of new offshoring facilities substantially reduce local employment. If the extensive margin of firms that begin to use offshore affiliates to manufacture components is large when costs fall, then the substitution of local employment across these firms may lead to significant negative employment consequences at the industry-level. Groizard, Ranjan, and Rodriguez-Lopez (2015) show that a reduction in costs of traded inputs induces job destruction primarily at less productive establishments, while larger establishments experience job creation. The next section develops our empirical strategy to assess the relative magnitude of these potentially offsetting effects of offshoring activity in more detail.

\footnotetext{
${ }^{13}$ Generally, the firms that begin to offshore following a reduction the costs to source inputs from a foreign affiliate can be drawn from the sets of firms that used any sourcing mode initially, $k \in\left\{O_{t i}, A_{t i}, I_{t i}, U_{i t}\right\}$. Yet, the change in domestic employment from firm that initially used an arms-length foreign supplier, $h \in A_{t i}$ has a negligible (i.e., second-order) effect, as they were already sourcing inputs from foreign destinations.
} 


\section{Empirical Approach}

The previous section highlighted the simultaneity of domestic and offshore hiring decisions and showed how variation in the effective tax rate on offshore activities can be used to identify the effects of offshore employment growth on domestic employment. We utilize changes in tax rates on overseas activity resulting from new bilateral tax treaties with foreign affiliate countries as an instrument for foreign affiliate employment. Here we describe bilateral tax treaties and the specific empirical specifications that we utilize to measure the domestic employment effects of offshoring at the multinational parent firm, industry, and regional level.

\subsection{Bilateral Tax Treaties}

Bilateral tax treaties (BTTs) are among the most pervasive global tax policies, with more than 1500 accords in place, and they govern several aspects of how taxes on international income are levied (Easson 2000). The intended purpose of these tax conventions, as stated in the preamble of the model U.S. tax treaty, is to provide for the avoidance of double taxation between contracting states and to limit tax evasion. ${ }^{14}$ Double taxation occurs when a lack of coordination between countries' taxing authorities results in the same income being taxed in two jurisdictions, raising the effective tax rate above its statutory level. The provisions within BTTs define the appropriate tax base, define taxable agents (e.g., permanent establishments), and put in place relief methods for any foreign taxes paid. In this regard, double-taxation relief is achieved via tax rules rather than statutory tax rates.

Even though our sample comes from the U.S., where firms can claim a credit for foreign taxes paid, it is well known that differences in the application of tax rules across countries still lead to substantial double-taxation in practice. A key determinant of the proper allocation of earned income across jurisdictions is the transfer price - the price charged between related parties (in our case the parent firm and its offshore affiliate) for goods, services, and/or use of assets. Though much attention is given to the fact that firms can strategically adjust transfer prices to minimize their overall tax burden, government tax authorities also have incentives to impose transfer-pricing rules that allocate larger shares of earned income to their respective jurisdictions. Such inconsistencies

\footnotetext{
${ }^{14}$ See http://www.treasury.gov/press-center/press-releases/Documents/hp16801.pdf for listing of the U.S. Model Tax Treaty, which is very similar to the model treaty from the OECD.
} 
in the application of administrative tax rules may result in double taxation. Ackerman and Hobster (2001) note that over 80 percent of multinational firms responding to Ernst \& Young surveys in the late 1990s reported that such transfer-pricing issues across tax jurisdictions were the root cause of their incidence of double taxation.

Bilateral tax treaties explicitly provide a mechanism for multinational firms to challenge their tax liabilities when facing double taxation. Each treaty closely follows the provisions of the U.S. model treaty, in which Article 25 stipulates that "The competent authority shall endeavor, if the objection appears to it to be justified and if it is not itself able to arrive at a satisfactory solution, to resolve the case by mutual agreement with the competent authority of the other Contracting State, with a view to the avoidance of taxation which is not in accordance with the Convention. ... The competent authorities of the Contracting States shall endeavor to resolve by mutual agreement any difficulties or doubts arising as to the interpretation or application of the Convention." This statement regarding the mutual agreement procedure (MAP) recognizes that many of the specific operations of multinational firms may have non-standard tax consequences. With a BTT in place between the U.S. and an offshore affiliate's host country, firms with unique tax circumstances have the opportunity to interact with both national tax agencies to reduce or eliminate the incidence of double taxation, and lower their effective tax rate on income from offshore activities. It is important to note that the MAP for tax grievances is available only with regard to activities that take place within a treaty partner. ${ }^{15,16}$

As an example, suppose that a U.S. multinational firm has an affiliate in France and earns $\$ 100$ million worldwide. The respective tax authorities may both claim that $\$ 60$ million of the firm's total economic activity took place within its own jurisdiction, which is clearly in error as there is only $\$ 100$ million of total income. Such a disagreement between the U.S. and French jurisdictions subjects the multinational firm to a form of double-taxation. However, with a BTT in place, the U.S. firm would have the right to request a 'correlative adjustment' to its tax liabilities from the competent authorities of each tax agency, so that the total taxes paid reflect the single $\$ 100$ million

\footnotetext{
${ }^{15}$ The availability of the MAP only with countries for which a tax treaty is in place is clearly stated in U.S. IRS documents; e.g., see http://www.irs.gov/Individuals/International-Taxpayers/Competent-Authority-Assistance.

${ }^{16}$ Statistics reported from competent authorities across the OECD indicate that the overwhelming majority of requests by multinational firms do result in a reduction in tax liabilities. The OECD collects reported statistics on MAP activity from its member countries, which can be found at: http://www.oecd.org/unitedstates/countrymutualagreementprocedurestatistics2006-2010.htm.
} 
in income.

Differences in the application of institutional tax rules across sectors lead to differences in the incidence of double-taxation across industries, even though statuary tax rates may be constant across industries. For example, in industries that use homogenous inputs (such as wheat, steel, corn, etc.), where the appropriate transfer-prices are relatively well-known, there is less scope for countries to misattribute the location of economic activity and incorrectly levy taxes on multinational firms' income. However, for firms that procure highly differentiated, specific, or intangible inputs from offshore suppliers, there is a much greater potential for double taxation as administrative rules are applied less consistently. As a consequence, BTT provisions limiting the incidence of double taxation are much more important for firms in industries that use differentiated versus homogeneous inputs. Blonigen, Oldenski, and Sly (2014) provide evidence confirming that the effects of BTTs on foreign affiliate activity and the entry of new foreign affiliates are much larger for industries that use differentiated inputs more intensively. In the empirical analysis below, we find similar differences across industries, based on the Rauch (1999) measure of input differentiation.

In our empirical analysis, we will use the introduction of BTTs as an instrument for foreign affiliate employment, to resolve the simultaneity between parent and affiliate employment demonstrated in equations (9) and (7) above. If BTTs had a direct effect on parent employment, this would violate the exclusion restriction, rendering BTTs invalid as an instrument. However, there are explicit provisions within treaties that mitigate this concern. Article 22 of the OECD model treaty details the Limitation of Benefits provision, which explicitly prohibits a multinational firm from claiming benefits through an affiliate in a treaty partner for activities that that took place in a non-treaty country, or in a country with a separate accord in place. Hence, the BTT language explicitly rules out direct effects on the costs of domestic activities, supporting the validity of the BTT as an instrument for foreign affiliate employment. ${ }^{17}$

\footnotetext{
${ }^{17}$ Some prior work suggests that BTTs may reduce effective tax rates through channels other than mitigating double taxation. Davies (2003) shows that by simply prohibiting the use of deductions for foreign taxes paid, the OECD model treaty will lead to larger incentives to invest abroad. Thus, even without explicit coordination in tax rates between nations, tax competition under a BTT leads to reduced tax liabilities for multinational firms. In addition, Chisik and Davies (2004) provide direct evidence that BTTs reduce withholding rates by the foreign jurisdiction on repatriated income, which should increase incentives for FDI and foreign affiliate activity. Note that all of these channels incentivize increased foreign affiliate activity rather than directly affecting the incentives to undertake domestic activities.
} 


\section{$3.2 \quad$ Affiliate-level analysis}

We begin the empirical analysis by confirming that BTTs substantially increase foreign affiliate employment by reducing effective tax rates on income from affiliate activity. From the model, equations (7) and (9) are a linear simultaneous equations system reflecting optimal hiring choices of the parent firm and its affiliate. Solving this system for affiliate employment yields the following estimating equation.

$$
\ln m_{a t}=a_{a}+b_{t i}+\beta_{a} B T T_{d t}+\epsilon_{a t} .
$$

In the model, affiliates are defined based on parent $h$, country $d$, and industry $i$, so we combine these subscripts into one subscript $a$ indicating an individual affiliate. ${ }^{18} m_{a t}$ is employment for affiliate $a$, and $\epsilon_{a t}$ is an error term. We measure exogenous changes in effective tax rates $\tau_{d t i}$ using an indicator for the presence of a bilateral tax treaty between the U.S. and affiliate country $d$, $B T T_{d t}$. Although this measure only varies by country and year, we stratify the analysis by high vs. low input differentiation to capture the heterogeneous effects of BTTs in this dimension, discussed in the previous subsection. We classify a firm as having high input differentiation if its share of differentiated inputs is above 0.6 and low differentiation if its share of differentiated inputs is below 0.6, using the Rauch (1999) measure. ${ }^{19}$

The regression equation (12) also includes affiliate $\left(a_{a}\right)$ and industry $\times$ time $\left(b_{t i}\right)$ fixed effects. By including fixed effects for both the cross-sectional unit (affiliate) and for time, this specification is equivalent to a panel difference-in-differences research design (Bertrand, Duflo, and Mullainathan 2004), with a generalization that allows for different time trends across industries. All diff-in-diff analyses make a common-trends assumption to achieve identification. In our context, average employment growth for affiliates in countries without BTTs must reflect average employment growth for affiliates in countries newly receiving a BTT, under a counterfactual where they did not receive a BTT. The inclusion of industry $\times$ time trends narrows this counterfactual comparison to firms in the same industry.

We use an event-study analysis, following Jacobson, LaLonde, and Sullivan (1993), to rule

\footnotetext{
${ }^{18}$ For simplicity, we treat sibling affiliates in the same industry and country as a single affiliate. Sibling affiliates in different countries or different industries remain distinct.

${ }^{19}$ This cutoff was chosen based on heterogeneity in industry-level responsiveness to BTTs by level of differentiation, which shows a clear break at a differentiated input intensity of 0.6 .
} 
out violations of the common-trends assumption that are reflected in pre-BTT trends in affiliate employment. In particular, we estimate

$$
\ln m_{a t}=a_{a}+b_{t i}+\sum_{j=-s}^{s} \kappa_{j} \cdot \mathbf{1}\left(t-y_{d}=j\right)+\epsilon_{a t},
$$

where $y_{d}$ is the year in which country $d$ received a BTT and $\mathbf{1}\left(t-y_{d}=j\right)$ is an indicator for each year $j$ before and after BTT implementation. This specification is a strict generalization of (12), in which the vector $\kappa_{j}$ reflects the time pattern of affiliate employment responses in each year preceding and following the introduction of a BTT. Figure 1 plots these coefficients separately for affiliates in high and low input differentiation industries and including the country-level controls described below. ${ }^{20}$ All coefficients are measured relative to year 0, in which the BTT was implemented. First, consider high differentiation industries, in which BTTs substantially reduce effective tax rates. In the three years preceding the introduction of a BTT, the $\kappa_{j}$ estimates are close to zero and relatively flat over time, indicating that affiliates that would soon receive a treaty were growing at a similar rate to those that would not receive a treaty, yielding zero estimated treatment effect. In other words, there does not appear to be a confounding pre-trend in the three years preceding treaty introduction. Only after the BTT is introduced do treaty and non-treaty affiliate growth rates diverge, as indicated by the jump in $\kappa_{1}$ compared to $\kappa_{0}$. The absence of employment effects prior to BTT implementation is consistent with prior evidence finding that increased foreign affiliate activity and new affiliate entry occur only after BTTs enter into force (Blonigen, Oldenski, and Sly 2014; Davies, Norback, and Tekin-Koru 2009). In contrast to the results for affiliates in high input differentiation industries, low input differentiation industry affiliates see little effect, consistent with the notion that BTTs have minimal effects on effective tax rates for affiliates in these industries.

The three years before BTT introduction show no evidence of confounding trends, while in years further removed from BTT introduction, it appears that average growth rates for affiliates that would later receive a treaty were larger than those that would not, as seen in the difference between $\kappa_{\leq-4}$ and $\kappa_{-3}$. Distant trends are extremely unlikely to better predict post-treatment counterfactual employment growth than closer pre-trends. Variation more than 4 years prior to BTT implementation is confounded by a substantial change in the composition of affiliates. Figure

\footnotetext{
${ }^{20}$ Results are nearly identical when omitting these additional controls.
} 
2 shows the number of affiliates that are continuously observed for $t$ years before and after their respective country's BTT implementation date. The number of observations declines by more than 45 percent for high input differentiation affiliates when expanding the window from \pm 3 to \pm 4 years. This is to be expected, as the average life span of an affiliate in our sample is 5.6 years and a number of countries enter the sample 3 years before BTT implementation, as shown in Figure 3. Based on these facts, we restrict attention to observations within 3 years of BTT implementation, indicated by the gray areas on Figure 1. If anything, using a wider window would yield larger estimated effects, so this restriction is conservative. Imposing the window restriction yields our affiliate-level estimating equation.

$$
\begin{array}{r}
\ln m_{a t}=a_{a}+b_{t i}+\beta_{A} \mathbf{1}\left(t-y_{d} \in[1,3]\right)+\beta_{<-3} \mathbf{1}\left(t-y_{d}<-3\right)+\beta_{>3} \mathbf{1}\left(t-y_{d}>3\right) \\
+X_{a t}+\epsilon_{a t} .
\end{array}
$$

The coefficients $\beta_{<-3}$ and $\beta_{>3}$ absorb variation in affiliate employment outside the \pm 3 year window. The coefficient of interest, $\beta_{A}$, reflects differences in employment growth between BTT and nonBTT affiliates before and after BTT introduction, within the \pm 3 year window, controlling for arbitrary industry time trends.

We estimate changes in affiliate employment using specifications with and without controls, $X_{a t}$, which fall in two categories. The first set captures time-varying country-level determinants of offshoring. Following the knowledge capital model of MNEs (Markusen 2002), these variables are defined in terms of country pairs, where one country is the U.S. and the other is the affiliate's country. ${ }^{21}$ They include the log sum of the two countries' GDPs, the log squared difference in GDPs, the log difference in skilled labor endowments, log trade costs, a bilateral investment treaty (BIT) dummy, a free trade agreement (FTA) dummy, and the exchange rate. The second set captures potential spillover effects from BTTs between the U.S. and sibling affiliates' countries and between sibling affiliates' respective countries. We include a "parent-sibling BTT" control reflecting the share of the affiliate's siblings' total employment that is covered by a BTT with the U.S. and an "affiliate-sibling BTT" control reflecting the share of the affiliate's siblings' total employment that

\footnotetext{
${ }^{21}$ The knowledge capital model captures the incentives to pursue vertical vs. horizontal FDI, which may be important given the evidence in Harrison and McMillan (2011) that the labor market consequences of foreign offshoring may differ by the motives of the parent firm.
} 
is covered by a BTT with the sibling's country. As we will see below, the inclusion or exclusion of either set of controls has little influence on the estimated effects on affiliate or domestic employment.

\subsection{Multinational parent-level analysis}

Given estimates of BTTs' effects on affiliate employment, our next objective is to measure the effect of exogenous changes in affiliate employment on parent employment. In the model, this effect is given by $\gamma_{1}^{\prime}$ in (9), which is positive and falls between zero and one. Since $\ln m_{t}(h)$ and $\ln s_{t}(h)$ are simultaneously determined, we will not consistently estimate $\gamma_{1}^{\prime}$ by simply observing the correlation between parent and affiliate employment; the observed effect will likely be biased upward, since $\gamma_{1}$ in (7) is positive. However, the effective tax rate on income from foreign affiliate activities, $\ln \tau_{d t i}$, directly affects affiliate employment in (7) but is excluded from the parent employment expression (9), so we can consistently estimate $\gamma_{1}^{\prime}$, by using the BTT indicator as an instrument for log affiliate employment.

Since many parent firms have multiple affiliates, we must aggregate employment across siblings to yield total affiliate employment for parent firm $h$ in year $t$, which we define as $M_{h t} \equiv \sum_{a \in h} m_{a t}{ }^{22}$ Hence, our objective is to estimate

$$
\ln s_{h t}=c_{h}+d_{t}+\beta_{P} \ln M_{h t}+X_{h t}+\varepsilon_{h t}
$$

where $s_{h t}$ is domestic employment, $M_{h t}$ is the parent's total affiliate employment, $c_{h}$ and $d_{t}$ are parent and time fixed effects, $X_{h t}$ is a vector of parent-level controls (described below), and $\varepsilon_{h t}$ is an error term. Following the theory, we seek to estimate (15) using variation in BTTs as an instrument for $\ln M_{h t}$.

The affiliate-level regression (14) yields predicted values for the log of affiliate employment, $\widehat{\ln m_{a t}}$. We must aggregate these values across siblings to generate a predicted value for the $\log$ of total employment for all affiliates of a given parent firm. We convert predicted values for the $\log$ of affiliate employment into predicted values for the level of affiliate employment using a nonparametric "smearing" procedure from Duan (1983) that accounts for the variance of the

\footnotetext{
${ }^{22}$ Recent work by Antràs, Fort, and Tintelnot (2014) argues that the number of affiliates comprising a parent firm's total offshore employment likely influences the effects of offshore activity on parent firm productivity, which can subsequently impact the employment effects we estimate here. By simply summing employment across affiliates, we are abstracting from this mechanism.
} 
predicted value estimates. ${ }^{23}$ We then sum these employment level estimates across sibling affiliates to generate predicted total affiliate employment for a given parent firm, $\widehat{\ln M_{h t}}$.

Because of the nonlinearity in this aggregation procedure, It is not appropriate to simply plug the estimated $\log$ total affiliate employment, $\widehat{\ln M_{h t}}$, into (15) to complete the two-stage least squares procedure. This would be an example of so-called "forbidden regression" in which a nonlinear firststage estimate is plugged into a linear second stage (Wooldridge 2002; Angrist and Pischke 2009). The standard solution in this situation is to use the predicted value for log total affiliate employment as an instrument for the observed log total affiliate employment. Thus, we run a standard IV regression for (15), with the predicted $\widehat{\ln M_{h t}}$ as an instrument for the observed $\ln M_{h t} \cdot{ }^{24}$

Equation (15) includes parent-level versions of the same controls that appear in the affiliate-level regression, (14). We generate employment-weighted averages across sibling affiliates, weighting by each affiliate's lagged share of the parent's total affiliate employment.

$$
X_{h t}=\sum_{a \in h} \varphi_{a, t-1} X_{a t} \quad \text { where } \varphi_{a, t-1} \equiv \frac{m_{a, t-1}}{M_{h, t-1}}
$$

where $X_{a t}$ is the affiliate country level control, $\varphi_{a, t-1}$ is affiliate $a$ 's share of firm $p$ 's total affiliate employment in year $t-1$, and $X_{p t}$ is the resulting parent-level control. We use lagged employment shares to mitigate concerns about endogenous employment shares, though controls with contemporaneous weights and unweighted averages yield very similar results, as do specifications omitting the controls.

\subsection{Industry-level analysis}

As discussed above, we are interested not only in the effects of offshoring on employment within U.S. multinational firms, but also in effects on the broader labor market. In particular, we would like to capture two margins of adjustment to offshoring that are absent in the analysis of multinational firms alone. First, the changes in employment at multinational parents may be partly offset by equilibrium employment adjustment at other domestic firms in the industry. Second, declining costs of offshore activity will likely motivate some firms to become multinational firms by opening new

\footnotetext{
${ }^{23}$ The smearing adjustment is necessary as a consequence of Jensen's inequality. A parametric approach assuming normally distributed errors yields nearly identical results to those presented here.

${ }^{24}$ Wooldridge (2002) presents this approach as "procedure 18.1."
} 
affiliates. Since these firms are not available in the BEA data before they become multinational firms, we cannot observe their employment responses in the multinational parent level analysis. To capture these broader effects of offshoring, we study the effects of increased offshore activity on employment by U.S. industries. We measure U.S. industry employment using County Business Patterns data at the 3-digit SIC level and link to the BEA International Surveys Industry (ISI) classification, resulting in 62 consistently identifiable industries.

We study the relationship between log domestic employment and log total affiliate employment at the industry level using the following specification.

$$
\ln L_{i t}=f_{i}+g_{t}+\ln M_{i t}+e_{i t}
$$

where $L_{i t}$ is total domestic employment in industry $i$ in year $t, M_{i t}$ is total foreign affiliate employment in the industry, and $f_{i}$ and $g_{t}$ are industry and time fixed effects. As with the parent-level regressions, we aggregate from the affiliate level to the industry level, taking care to address the nonlinearity of the aggregation method. We then instrument for observed log industry affiliate employment $\ln M_{i t}$, using predicted $\log$ industry affiliate employment $\widehat{\ln M_{i t}}$, aggregated up from the affiliate-level predicted values.

\subsection{Metropolitan-area analysis}

We also measure the domestic employment effects of offshoring at the local labor market level. This perspective adds yet another potential margin of labor market adjustment to the analysis by including potential employment spillovers across industries at the local labor market level. Our unit of analysis is the metropolitan area, and we use 305 time-consistent metro areas, constructed from

underlying county-level employment in the County Business Patterns data. Hence, our metro-area estimation equation is

$$
\ln L_{m t}=h_{m}+k_{t}+\ln M_{m t}+v_{m t},
$$

where $L_{m t}$ is metro area $m$ employment in year $t, h_{m}$ and $k_{t}$ are metro area and year fixed effects, and $v_{m t}$ is an error term. Our local measure of offshoring exposure, $M_{m t}$ is a weighted average of industry-level foreign affiliate employment. We construct industry-level foreign affiliate employment 
as described above, and the weights reflect the distribution of employment across covered industries in 1986, just before the start of our main analysis sample.

$$
M_{m t} \equiv \sum_{i} \varphi_{m i}^{1986} M_{t i} \quad \text { where } \varphi_{m i}^{1986} \equiv \frac{L_{m i}^{1986}}{\sum_{i^{\prime}} L_{m i^{\prime}}^{1986}}
$$

This measure captures each metro area $m$ 's exposure to foreign affiliate employment, following a procedure similar to Topalova (2010), Autor, Dorn, and Hanson (2013), and Kovak (2013). We generate an instrument for $\ln M_{m t}$ by constructing an otherwise identical measure that replaces observed industry affiliate employment, $M_{i t}$, with predicted industry affiliate employment, $\widehat{M_{i t}}$, as in the industry-level analysis.

\section{Data}

To implement our empirical strategy, we require data on multinational firms' employment at their U.S. parent and foreign affiliate locations, the implementation of new bilateral tax treaties (BTTs), industry-level characteristics that impact the effectiveness of these treaties in reducing double taxation, and employment outcomes by U.S. industries and local labor markets.

The Bureau of Economic Analysis (BEA) collects firm-level data on U.S. multinational company operations in its annual surveys of U.S. direct investment abroad. We use data on total employment by foreign affiliates of U.S. firms from these surveys as our measure of offshore activity. Using firmlevel data has two distinct advantages for our purpose. First, BEA firm-level data indicate if there is trade between U.S. parents and their foreign affiliates. Our instrumental variable strategy relies on tax treaties that impact within-firm trade, and thus we only use data on multinational affiliates that engage primarily in vertical FDI. Second, the likelihood of offshoring may differ across firms, and failing to account for unobserved firm-level characteristics might have led us to mis-identify the effects of offshoring. Each foreign affiliate in the dataset is assigned an industry classification based on its primary activity according to the BEA International Surveys Industry (ISI) system, which closely follows the 3-digit Standard Industrial Classification (SIC) system. ${ }^{25}$ We focus on non-service sectors, giving us a set of 2,142 firms with 17,117 foreign affiliates spanning 62 3-digit

\footnotetext{
${ }^{25}$ The BEA data use 3-digit SIC-based ISI codes for years prior to 1999. From 1999 onward, they use 4-digit NAICS-based ISI codes. For consistency, we convert the NAICS-based codes to 3-digit SIC-based ISI codes for the relevant years.
} 
industries and operating in 81 countries from 1987 to 2007.

Information about international tax treaties signed by the U.S. that we use to construct our instrument come from Internal Revenue Service and Treasury Department publications. ${ }^{26}$ The text of each treaty provides the signing date, ratification date, the general effective date, and the date of revisions if applicable. Treaties are often signed in years prior to when they become effective, and several country pairs have also renegotiated their BTTs over time. We use the effective date of the original signing to indicate when countries have a treaty in place. If anything, this approach would bias us against finding a significant impact on foreign investment if there were anticipatory responses prior to the effective date of a new BTT. ${ }^{27}$ Table 1 provides a list of countries that have a new BTT with the U.S. during our sample period, and the corresponding year it became effective. The set of new treaties signed by the U.S. covers many regions of the world, with nations that differ substantially in their volumes of FDI activities.

Blonigen, Oldenski, and Sly (2014) have shown that BTTs only affect the FDI activity of firms in highly differentiated industries. This is because determining the allocation of total global income across countries is much more difficult for these more complex firms, which produce unique products with no comparable benchmark to use in determining relevant transfer prices and allocating global value added across countries within a single firm. Empirically, we define the level of differentiation as the share of inputs traded on an organized exchange or with a published reference price. There are two components to these data. First, Rauch (1999) documented which goods are traded on an organized exchange, are exchanged through specific contracts, and which are offered at referenced prices. Products are classified at a highly disaggregated level. Second, Nunn (2007) uses U.S. input-output tables to measure the intensity with which each input is used in the industry-specific production process. These data provide detailed information about the variation in factor usages by their level of product differentiation.

The original industry-level data on factor usage correspond to the 4-digit SITC revision 2 classification system, which we convert to 3-digit SIC-based ISI codes using correspondences available from the U.S. Bureau of Economic Analysis. When the 3-digit level spans observations for several 4-digit industries, we use the average fraction of inputs traded on an organized exchange or with an

\footnotetext{
${ }^{26}$ See IRS.gov, United States Income Tax Treaties A-Z.

${ }^{27}$ Davies (2003) considers revisions to tax treaties and, similar to previous studies, finds no impact on foreign investment activity.
} 
available reference price. Data on industry-level characteristics are limited to observations from the U.S. for a single year, and so we must treat them as constant across all countries and years. After aggregating, we have coverage for 62 separate industries concentrated in non-service sectors. ${ }^{28}$

As described in Section 2, we can also use our framework to estimate the effect of firm-level offshoring on domestic employment at the industry and metropolitan area levels. To do so, we use data on employment by industry and metropolitan statistical area (MSA) from the U.S. Census Bureaus's County Business Patterns (CBP). These data report total employment at private business establishments in covered industries by industry and county. ${ }^{29}$ We aggregate industry data to match the 3-digit classification used in the BEA data and aggregate counties to construct 304 time-consistent metropolitan areas spanning our sample period.

We control for time-varying country-level determinants of offshoring using data compiled from several sources. Information regarding real GDP and trade costs come from the Penn-World tables. National incomes are expressed in trillions of U.S. dollars. Trade costs are measured using standard definitions of openness: 100 minus the trade share of total GDP. Skill differences across country pairs are measured using estimates of average educational attainment by Barro and Lee (2010). Observations of educational attainment in each country are available every five years; we linearly interpolate data for years between observations. Data indicating whether the U.S. has a bilateral investment treaty (BIT) with the destination country are from the United Nations Conference on Trade and Development (UNCTAD). The incidence of free trade agreements across countries is available from the U.S. Trade Representative. Annual exchange rate data are from the World Bank. For our affiliate-level regressions, we are able to use these controls at the country-level, as each affiliate only resides in one country. For the parent level specifications, we aggregate the country-level control variables to the parent firm-level using weighted averages with lagged affiliate employment weights, as described in Section 3.3.

Table 2 reports summary statistics for the individual foreign affiliates in our dataset, as well as for the U.S. parent firms that own them. The average firm in our sample has 4.7 foreign affiliates

\footnotetext{
${ }^{28}$ The use of aggregated sector data is driven completely by data constraints. It is worth noting that this aggregation limits the variation in the measures of inputs traded on organized exchanges, in addition to generating substantial measurement error surrounding firm-level use of differentiated inputs supplied by affiliates. However, each of these features only work against obtaining significant estimates of the impacts of treaties across industries.

${ }^{29}$ The CBP data provide full coverage in all industries except crop and animal production; rail transportation; National Postal Service; pension, health, welfare, and vacation funds; trusts, estates, and agency accounts; private households; and public administration.
} 
with total foreign employment of 3523 workers and total U.S. employment of 8645 workers.

\section{Results}

This section first describes the effects of BTTs on foreign affiliate employment, which we use to construct an instrument for observed variation in affiliate employment. We then use this exogenous variation to estimate the effects of increased offshore employment on domestic U.S. employment at the firm, industry, and metro area level.

\subsection{The Relationship between BTTs and Offshoring}

As illustrated in Section 2, offshore employment at the foreign affiliates of U.S. MNEs is determined jointly with the domestic U.S. employment of these firms. To address the endogeneity of offshoring to domestic employment, we exploit variation in the enactment of bilateral tax treaties (BTTs) to create a measure of exogenous declines in offshoring costs. Section 3 presented background on BTTs and demonstrated that affiliates in countries signing new treaties experienced similar employment growth in the years just before treaty implementation to those in countries without new treaties, ruling out differences in ongoing trends between BTT and non-BTT countries.

We now estimate the relationship between BTTs and offshoring, following (14). As explained in Section 3.2, we restrict attention to observations within 3 years of BTT implementation to avoid potentially confounding out-year effects. As a robustness check, we also estimated the relationship between BTTs and and affiliate employment without this restriction, yielding a much larger and more precisely estimated effect of BTTs on affiliate employment. Hence, by focusing on the more narrow window, out estimates are conservative. ${ }^{30}$

Each successive column in Table 3 reports estimates from specifications of equation (14) for high- and low-input differentiation industries. We classify a firm as high differentiation (High dif) if its industry's share of differentiated inputs is above 0.6 and as low differentiation (Low dif) if its share of differentiated inputs is below 0.6. ${ }^{31}$ Consistent with Blonigen, Oldenski, and Sly (2014), Table 3 shows that BTTs are associated with a positive and significant increase in foreign affiliate

\footnotetext{
${ }^{30}$ The unrestricted results are available from the authors by request.

${ }^{31}$ This cutoff was chosen based on a graph of industry-level responsiveness to BTTs by level of differentiation, which shows a clear structural break at a differentiated input intensity of 0.6.
} 
employment at firms operating in industries that use relatively high shares of differentiated inputs ("high dif" firms), but not for firms in industries with low differentiated input shares ("low dif" firms), reflecting the fact double taxation is a more severe issue in high differentiation industries (see Section 3.1).

Most of the firms in our sample have multiple affiliates in different countries. We refer to affiliates of the same parent as "siblings." When an affiliate's country receives a new treaty with the U.S., it may affect its siblings as well, as can treaties between two siblings' countries. To address these possibilities, our preferred empirical approach in columns 5 and 6 of Table 3 controls for the existence of BTTs between the U.S. and an affiliate's sibling countries, as well as treaties between the affiliate country and its sibling's countries. We define "Parent-Sibling BTTs" as the share of total employment at siblings of affiliate $a$ in time $t$ that is covered by a BTT with the U.S.. Similarly, "Affiliate-Sibling BTTs" is the share of total employment at siblings of affiliate $a$ in time $t$ that is covered by a BTT with the country in which affiliate $a$ is located.

The estimates in column 5 of Table 3 suggest that firms in differentiated industries increase their affiliate employment by 12.4 percent in response to a new BTT. ${ }^{32}$ The average affiliate in our sample has 748 employees, so this estimate corresponds to hiring an additional 93 workers on average. Along with this economically substantial effect of BTTs on foreign affiliate employment for high input differentiation industries, there is a strong statistical relationship. The partial Fstatistic for the BTT indicator in column 5 is 9.73. Thus, BTTs lower the effective tax rate on income from foreign affiliate activities, and hence can be used to identify the effects of foreign affiliate employment on domestic employment.

\subsection{The Impact of Offshoring on Firm-Level U.S. Employment}

As described in Section 3, we use the results presented in Table 3 to generate an instrument for offshoring by U.S. firms. To do this, we first obtain predicted values of log affiliate employment, $\widehat{\ln m_{a t}}$, for firms in both differentiated and nondifferentiated industries using the specifications from columns 5 and 6 of Table 3. We then aggregate these predicted values over all affiliates of the same U.S. parent firm. Because the first stage uses logs (rather than levels) of affiliate employment, we must be careful to properly adjust for the variance in estimating $\widehat{\ln m_{a t}}$ using the

\footnotetext{
${ }^{32} 100 *(\exp (0.117)-1)=12.4$
} 
smearing technique described by Duan (1983), as discussed in Section 3.3. This procedure yields the estimated log total affiliate employment for each U.S. parent, $\widehat{\ln M_{h t}}$. Because we are imposing a nonlinear transformation on the first-stage predictions, we can not simply plug $\widehat{\ln M_{a t}}$ into a second stage regression, as the predicted values will not necessarily be orthogonal to the first stage error term. Instead, we follow Angrist and Pischke (2009) and Wooldridge (2002) by using $\widehat{\ln M_{a t}}$ as an instrument for parent-level offshoring in (15). See Section 3.3 for details, and note that the IV standard errors are unaffected by the affiliate level instrument generation procedure preceding the standard IV analysis at the parent level (Wooldridge 2002).

Table 4 presents the parent-level OLS and IV results. Complete parent-level first stage results are in the appendix, and first-stage partial F-statistics are reported in Table 4. The F-statistics are all very large, alleviating any concerns about a weak instruments problem. Large F-statistics are common when implementing this instrument generation procedure to account for nonlinearity in the first stage (see example 18.3 in Wooldridge (2002)). We also report F-statistics for the excluded BTT instrument in the affiliate level regressions presented in Table 3. These are much smaller than those of parent-level first stage, but are still large enough to eliminate concerns about weak instruments. ${ }^{33}$

We first consider the naive firm-level OLS regression of domestic parent employment on total foreign affiliate employment in Column 1 of Table 4. There is a very large positive correlation between the total foreign affiliate employment by a U.S. MNE and its domestic U.S. employment, even when controlling for firm and year fixed effects and the full set of controls. The average firm in our sample experiences an increase in total foreign affiliate employment of about 10 percent per year. The OLS results suggest that a 10 percent increase in foreign employment is associated with a 4.64 percent increase in domestic U.S. employment at the parent firms doing the offshoring. However, as shown in Section 2, failure to account for the simultaneity of foreign and domestic hiring likely results in substantial upward bias, which we can see quite clearly by contrasting the OLS results in Table 4 with those using the IV approach in Column 2.

The IV coefficient on $\ln M_{h t}$ in Column 3 is also positive and highly significant. However, its magnitude is much lower than that of the OLS result. Using the IV estimate, a 10 percent increase

\footnotetext{
${ }^{33}$ Stock and Yogo (2005) report that 8.96 is the critical value for the partial F-statistic needed to reject the null hypothesis that the actual size of a 5 percent test is greater than 15 percent.
} 
in foreign employment is associated with a 1.38 percent increase in domestic U.S. employment at the firms doing the offshoring. As shown in Section 5.1, a new BTT increases employment at affected affiliates by about 12.4 percent. This corresponds to about a 1.72 percent increase in domestic employment, or about 148 new U.S. workers for the average parent firm. If all of the firms in our sample were exposed to a fall in offshoring costs equivalent in magnitude to a new BTT, the domestic effect would be about 317,016 new U.S. jobs across all 2,142 firms on average. For each of our IV regressions, we also conducted a Hausman test of exogeneity for the corresponding OLS specification. In all cases, we reject the equality of OLS and IV, demonstrating the importance of accounting for the endogeneity of foreign affiliate employment.

The regressions presented in Table 4 also include several control variables to capture characteristics of the countries in which the firm has affiliates. As described in Section 4, each of these controls is aggregated from the affiliate country level to the parent firm level by taking a weighted average in which the weights are lagged affiliate shares of total foreign employment of the parent firm. ${ }^{34}$ The introduction of these controls does not change the estimated impact of offshoring on U.S. parent firm employment.

As shown in equation (11), in addition to the positive scale effects of offshoring that are exhibited on the intensive margin within existing MNEs, there may also be negative substitution effects on the extensive margin as some firms decide to alter their global organizational structure in response to the lower effective tax rate on income from offshore activities. As a result, these firms may substitute foreign employment at an offshore affiliate for workers that previously manufactured components in the U.S.

Thus, we expect that among the set of firms that open a new affiliate when offshoring costs fall, the gains in U.S. domestic employment are no greater than for firms that expand on the intensive rather than the extensive margin. Unfortunately, we do not observe whether a new offshore affiliate is performing activities that previously took place in the U.S. or at arms-length abroad. However, we can contrast the results for existing MNEs that open new affiliates following a BTT to those that do not. These results are presented in columns 4 and 5 of Table 4. As predicted, the coefficient on $\ln M_{h t}$ for firms opening new affiliates is much smaller than for firms that do not, suggesting the presence of both extensive margin substitution effects and intensive margin scale effects. The

\footnotetext{
${ }^{34}$ See Section 4 for more details on data sources and variable construction.
} 
results in columns 4 and 5 are significantly different from each other at the 1 percent level.

\subsection{Industry Level Effects of Offshoring}

The results presented in Section 5.2 only consider the impact of offshoring on employment at the firm doing the offshoring. However, the model presented in Section 2 shows that a fall in offshoring costs can also drive non-MNEs to become MNEs due to the fall in the effective cost of offshore affiliate activities. Thus, we would expect the labor market effects of offshoring to extend beyond the MNEs themselves. Similarly, domestic labor market equilibrium can also result in the effects of offshoring appearing outside multinational firms. (c.f., Groizard, Ranjan, and Rodriguez-Lopez (2015)) We use County Business Patterns (CBP) data on employment by industry to estimate the relationship between offshoring and labor market outcomes for all U.S. workers.

As described in Section 3.4, we aggregate from the affiliate level to the industry level, taking care to address the nonlinearity of the aggregation method, using the same technique as for the parent-level analysis. We then compare growth in total U.S. industry employment to growth in foreign affiliate employment in the same industry, using BTT-driven variation in industry affiliate employment as an instrument. Table 5 shows the relationship between offshore affiliate employment and U.S. employment at the industry level. Complete first stage results are in the appendix, and the first stage F-statistics are presented in Table 5. As in the firm-level analysis, the instrument is a very strong predictor of industry-level employment. Column 1 presents the OLS results, and column 2 shows the instrumental variable results.

As was the case at the firm-level, the industry-level OLS and IV specifications both show a positive and significant relationship between offshoring and U.S. domestic employment. And once again, the magnitude of the effect is significantly smaller when we address the simultaneity of offshore and domestic employment. In fact, at the industry level, the IV estimate is an order of magnitude smaller than the OLS estimate, confirming the importance of appropriately addressing this endogeneity issue.

Using the IV estimate, a 10 percent increase in foreign employment is associated with a 0.48 percent increase in domestic U.S. employment in that industry. As shown in Section 5.1, a new BTT increases employment at affected affiliates by about 12.4 percent. This corresponds to about a 0.60 percent increase in domestic industry-level employment. The average industry in our sample 
employs 480,890 U.S. workers. If all of the industries in our sample were exposed to a fall in offshoring costs equivalent in magnitude to a new BTT, the domestic effect would be about 2,885 new U.S. workers per industry or 178,891 new jobs over all 62 industries. The relationship between offshoring and domestic U.S. employment is much smaller at the industry level than at the firm level. This is consistent with the predictions of Section 2 because the industry level results capture both the extensive margin substitution effects, as some U.S. firms replace domestic labor with new foreign affiliate employment, and the positive scale effects that we saw in the parent-level results, as existing MNEs increase their employment both in the U.S. and at their foreign affiliates. Together, these two channels yield a net positive effect of increased foreign affiliate employment on domestic employment at the industry level.

\subsection{Local Labor Market Effects of Offshoring}

We are also interested in estimating how offshoring impacts employment in different local labor markets within the U.S. This perspective allows us to capture potential spillovers across industries that operate at the local level. We use time-consistent metropolitan statistical areas (MSAs) as our unit of geographic analysis. Since geographic locations differ in their concentrations of industrylevel activity and employment across sectors, we are able to measure the heterogeneous impacts that offshoring has on local labor markets within the U.S. Using each metro area's initial industry mix of employment, we construct a geographic measure of exposure to offshoring as a weighted average of industry-level foreign affiliate employment. We then instrument for this observed measure using an instrument that is constructed similarly, but using industry-level predicted total affiliate employment, reflecting the effects of BTTs on affiliate hiring.

Column 3 of Table 5 shows the MSA-level results. As with the aggregate industry-level results, the relationship between offshoring and employment is positive. It is also larger than the industry point estimate, suggesting the possibility of cross-industry spillovers. However, one cannot reject that the MSA coefficient is equal to the industry point estimate, so this comparison is merely suggestive. Note that the MSA level data include employment outcomes for workers outside of the 62 manufacturing industries that we use in the industry and firm level analyses, and suggest that the potential effects for the U.S. as a whole are larger when considered at the MSA level, rather than at the level of the industries doing the offshoring. If all of the 304 metro areas in our sample 
experienced a fall in offshoring costs equivalent to a new BTT, this would result in the hiring of an average of 3,248 new workers per MSA, or 987,392 in the U.S. as a whole. Future versions of this paper will more thoroughly examine the factors that determine whether a given industry or MSA is likely to see positive or negative labor market effects from offshoring, as well as controlling for other known determinants of employment at the industry and MSA levels.

\section{Conclusion}

The consequences of ever rising levels of offshoring activity by US multinational firms are consistently a source of debate for both the public and for policy makers. However the fact that offshore hiring and domestic employment are determined simultaneously has made it difficult for economists to provide clear answers about the relationship between the two. We contribute to this debate by providing estimates that rely on exogenous variation in offshoring costs, allowing us to infer the causal implications of greater offshoring employment for US labor market outcomes.

We use a model of offshoring activity by multinational firms to explicitly characterize the simultaneity between domestic and offshore hiring decisions, and to derive an empirical strategy that circumvents this source of endogeneity by exploiting variation in effective tax rates on offshoring activities that arise from the signing of bilateral tax treaties. We find economically modest but statistically significant positive effects of offshoring on domestic hiring within multinational parent firms. A 10 percent increase in employment within an offshore affiliate is associated with a 1.38 percent increase in employment at the U.S. parent firm. Intuitively, when offshoring costs fall, multinational firms take advantage of lower global production costs and hire more labor domestically to complement offshore workers. The IV estimates are less than one-third of the magnitude of the OLS results, indicating that the simultaneity of hiring decisions substantially biases estimates that fail to account for the endogeneity of offshore hiring to domestic employment.

The impact of offshoring is different when looking more broadly at industry-level employment. When offshoring costs fall, some firms may alter their global sourcing strategy and begin to substitute offshore facilities to perform activities that used to take place locally. This substitution can adversely affect employment outcomes for US workers. Looking within multinational firms that open new affiliates in countries that realize lower offshoring costs, we find that the benefits to do- 
mestic employment are half the size as those estimated for firms with existing affiliates. Moreover, at the industry-level the estimated impact of greater offshoring is one third the size of that estimated within multinational firms, yet it is still positive on net. Metro area estimates capture local spillovers across industries, and hence are larger than the industry estimates. Together, our results suggest that substantial substitution effects and substantial scale effects partly offset, yielding a positive net impact on US employment. 


\section{References}

Ackerman, Robert, and John Hobster. 2001. "Transfer pricing practices, perspectives, and trends in 22 countries." Tax Notes International 24 (12): 1151-8.

Angrist, Joshua D., and Jörn-Steffen Pischke. 2009. Mostly Harmless Econometrics: An Empiricist's Companion. Princeton, NJ: Princeton University Press.

Antràs, Pol, Teresa Fort, and Felix Tintelnot. 2014. "The Margins of Global Sourcing: Theory and Evidence From U.S. Firms." NBER Working Paper, no. 20772.

Antràs, Pol, and Elhanan Helpman. 2004. "Global Sourcing." Journal of Political Economy 112 (3): $552-580$.

Autor, David, David Dorn, and Gordon Hanson. 2013. "The China Syndrome: Local Labor Market Effects of Import Competition in the United States." American Economic Review 103 (6): 2121-2168.

Becker, Sascha O., Karolina Ekholm, and Marc-Andreas Muendler. 2013. "Offshoring and the onshore composition of tasks and skills." Journal of International Economics 90 (1): 91-106.

Bertrand, Marianne, Esther Duflo, and Sendhil Mullainathan. 2004. "How Much Should We Trust Differences-in-Differences Estimates?" The Quarterly Journal of Economics, pp. 249-275.

Blonigen, Bruce A., Lindsay Oldenski, and Nicholas Sly. 2014. "The Differential Effects of Bilateral Tax Treaties." American Economic Journal: Economic Policy 6 (2): 1-18. NBER working paper 17480 .

Brainard, S Lael, and David A Riker. 1997. "Are US multinationals exporting US jobs?” Technical Report, National Bureau of Economic Research.

Chisik, Richard, and Ronald B. Davies. 2004. "Asymmetric FDI and tax-treaty bargaining: theory and evidence." Journal of Public Economics 88:1119-1148.

Davies, Ronald B. 2003. "Tax treaties, renegotiations, and foreign direct investment." Economic Analysis and Policy 33:251-273.

Davies, Ronald B., Pehr-Johan Norback, and Ayca Tekin-Koru. 2009. "The effect of Tax Treaties on Multinational Firms: new evidence from micro-data." The World Economy 32 (1): 77-110.

Defever, Fabrice, and Farid Toubal. 2013. "Productivity, relationship-specific inputs and the sourcing modes on multinationals." Journal of Economic Behavior and Organization 94:34557 .

Desai, Mihir A, C Fritz Foley, and James R Hines. 2009. "Domestic effects of the foreign activities of US multinationals." American Economic Journal: Economic Policy 1 (1): 181-203.

Duan, Naihua. 1983. "Smearing Estimate: A Nonparametric Retransformation Method." Journal of the American Statistical Association 78 (383): 605-610.

Easson, Alex. 2000. "Do we still need tax treaties?" Bulletin for International Fiscal Documentation 54:619-625.

ErnstandYoung. 2015. "International Tax Alert: News from Transfer Pricing."

Feenstra, Robert C., and Gordon H. Hanson. 2003. "Global production sharing and rising inequality." In Handbook of International Trade, edited by E. Kwan Choi and James Harrigan, Volume 1, 146. Blackwell Publishing Ltd. 
Feenstra, Robert C, and Gordon H Hanson. 1999. "The impact of outsourcing and high-technology capital on wages: estimates for the United States, 1979-1990." Quarterly Journal of Economics, pp. 907-940.

- 2005. "Ownership and Control in Outsourcing to China: Estimating the Property-Rights Theory of the Firm." Quarterly Journal of Economics, no. 2:729-761.

Goos, Maarten, and Alan Manning. 2007. "Lousy and Lovely Jobs: The Rising Polarization of Work in Britain." Review of Economics and Statistics 89 (1): 118-133 (2015/06/28).

Goos, Maarten, Alan Manning, and Anna Salomons. 2009. "Job polarization in Europe." The American Economic Review 99 (2): 58-63.

Groizard, Jose L., Priya Ranjan, and Antonio Rodriguez-Lopez. 2015. "Trade costs and job flows: evidence from establishment-level data." Economic Inquiry 53 (1): 173-204.

Grossman, Gene M., and Esteban Rossi-Hansberg. 2008. "Trading Tasks: A simple theory of offshoring." The American Economic Review 98 (5): 1978-1997.

Harrison, Ann, and Margaret McMillan. 2011. "Offshoring jobs? Multinationals and US manufacturing employment." Review of Economics and Statistics 93 (3): 857-875.

Head, Keith, and John Ries. 2002. "Offshore production and skill upgrading by Japanese manufacturing firms." Journal of international economics 58 (1): 81-105.

Hummels, David, Rasmus Jørgensen, Jakob Munch, and Chong Xiang. 2014. "The Wage Effects of Offshoring: Evidence from Danish Matched Worker-Firm Data." The American Economic Review 104 (6): 1597-1629.

Jacobson, Louis S, Robert John LaLonde, and Daniel Gerard Sullivan. 1993. "Earnings Losses of Displaced Workers." The American Economic Review 83:685-709.

Kovak, Brian. 2013. "Regional Efects of Trade Reform: What is the Correct Measure of Liberalization?" American Economic Review 103 (5): 1960-1976.

Markusen, James R. 2002. Multinational Firms and the Thoery of International Trade. MIT Press.

Monarch, Ryan, Jooyoun Park, and Jagadeesh Sivadasan. 2014. "Gains from offshoring? Evidence from U.S. Microdata." University of Michigan.

Muendler, Marc-Andreas, and Sascha O. Becker. 2010. "Margins of multinational labor substitution." The American Economic Review 100 (5): 1999-2030.

Oldenski, Lindsay. 2014. "Offshoring and the Polarization of the US Labor Market." Industrial and Labor Relations Review 67 (3): 734-761.

Olney, William W. 2012. "Offshoring, immigration and the native wage distibution." Canadian Journal of Economics 45 (3): 830-56.

Ottaviano, Gianmarco, Giovanni Peri, and Greg Wright. 2013. "Immigration, Offshoring and American Jobs." American Economic Review 103 (5): 1925-1959.

Rauch, James E. 1999. "Networks versus markets in international trade." Journal of International Economics 48 (1): 7-35.

Slaughter, Matthew J. 2000. "Production Transfer within multinational enterprises and American wages." Journal of International Economics 50, no. 2.

- 2001. "International trade and labor-demand elasticities." Journal of International Economics 54 (1): 27-56. 
—. 2009. "How U.S. multinational companies strengthen the U.S. Economy." Technical Report, Business Roundtable and Business Roundtable and The United States Council Foundation.

Stock, James H, and Motohiro Yogo. 2005. "Testing for Weak Instruments in Linear IV Regression." In Identification and Inference for Econometric Models: Essays in Honor of Thomas Rothenberg, edited by Donald W. K. Andrews and James H. Stock, 80-108. Cambridge University Press.

Topalova, Petia. 2010. "Factor Immobility and Regional Impacts of Trade Liberalization: Evidence on Poverty from India." American Economic Journal: Applied Economics 2, no. 4.

Wooldridge, Jeffrey M. 2002. Econometric Analysis of Cross Section and Panel Data. Cambridge, MA: MIT Press. 
Figure 1: Relationship Between BTTs and Foreign Affiliate Employment - Event Study Analysis

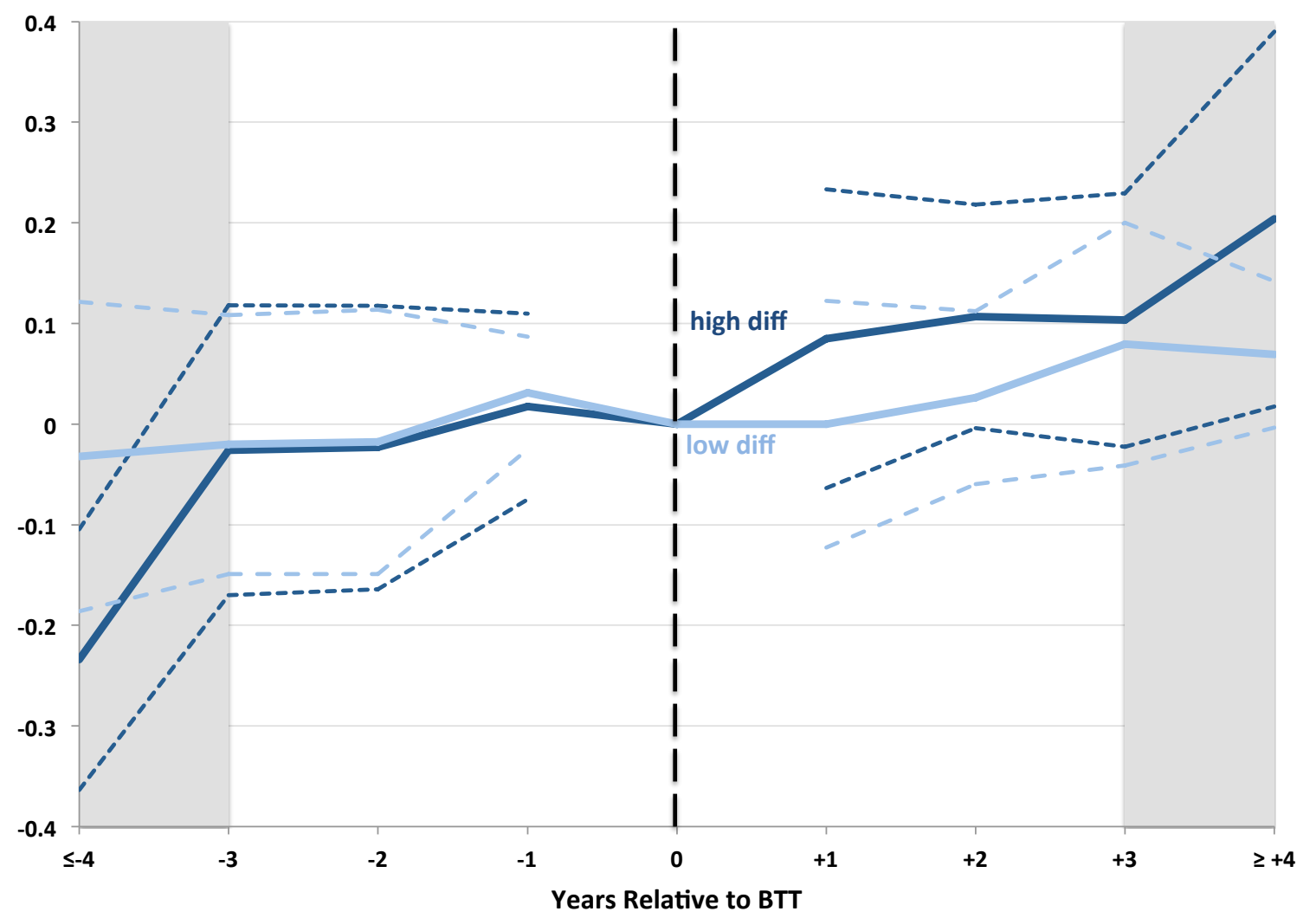

Source: Authors' calculations based on BEA data. Solid lines represent event study treatment effect coefficients, measured with respect to $t=0$, the year of BTT implementation. Dashed lines reflect 95 percent confidence intervals from standard errors clustered by country. Specification includes affiliate and industry $\times$ time fixed effects and full set of country $\times$ time level controls, described in the text. High diff restricts to affiliates with differentiated good input share of 0.6 or greater, and low diff less than 0.6. Gray regions indicate that our main analysis restricts attention to employment effects within three years of BTT implementation. See text for details. 
Figure 2: Number of Sample Affiliates Spanning Windows Around BTT Implementation
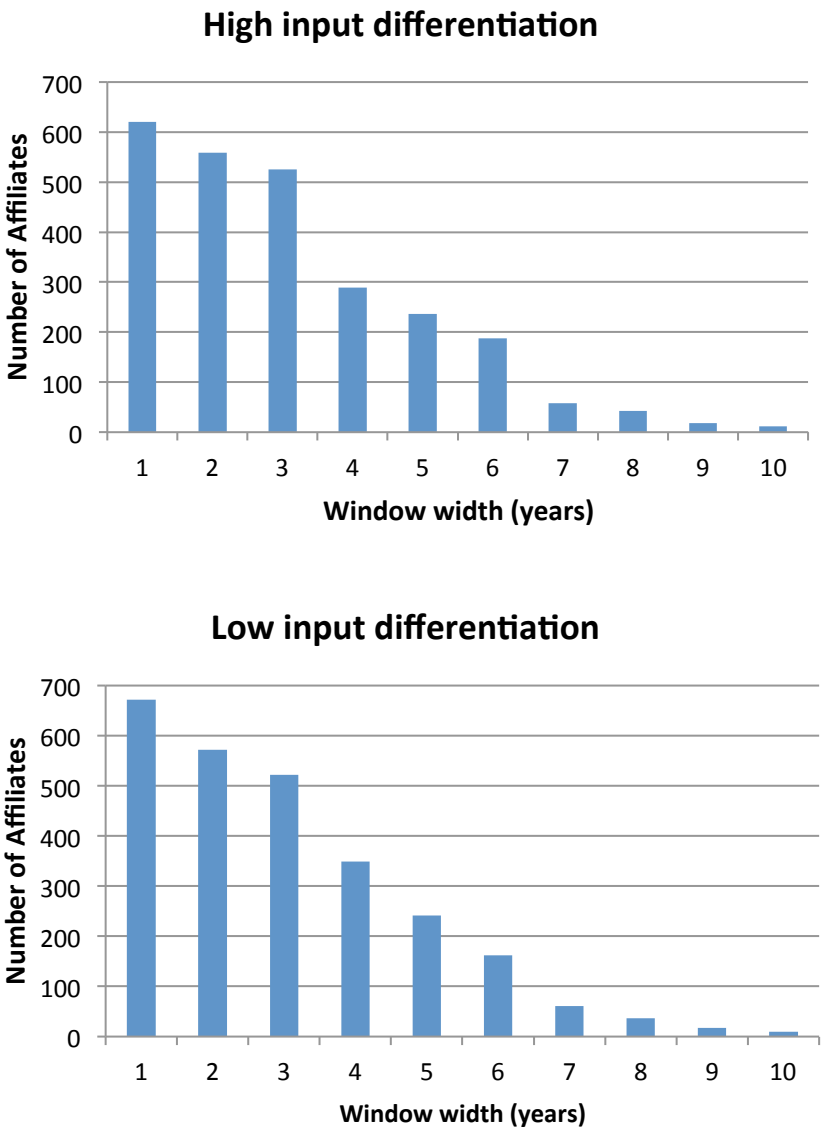

Source: Authors' calculations based on BEA data. Y-axis reports the number of affiliate observations that span the time period $\pm t$ years around the relevant country's BTT implementation, where $t$ is the value listed on the $\mathrm{x}$-axis. 
Figure 3: Sample Coverage Relative to BTT Implementation

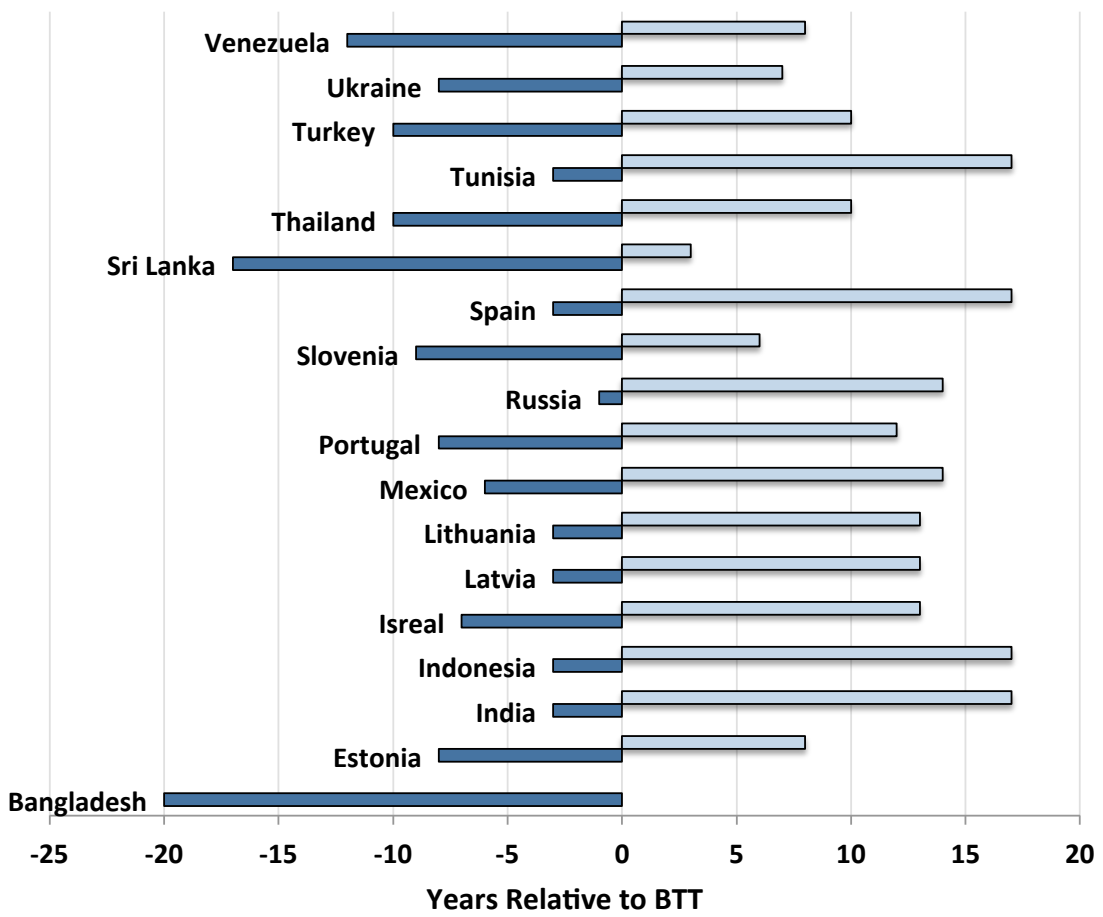

Source: Authors' calculations based on BEA data. Each country shown has a new BTT during our sample period. Darker bars show the number of available years before the BTT and lighter bars show the number of available years after the BTT. 
Table 1: Countries with New Treaties in Effect

\begin{tabular}{ll|ll}
\hline Country & Date & Country & Date \\
\hline Bangladesh & 2007 & Russia & 1993 \\
Estonia & 1999 & Slovenia & 2001 \\
India & 1990 & Spain & 1990 \\
Indonesia & 1990 & Sri Lanka & 2004 \\
Israel & 1994 & Thailand & 1997 \\
Latvia & 1994 & Tunisia & 1990 \\
Lithuania & 1994 & Turkey & 1997 \\
Mexico & 1993 & Ukraine & 2000 \\
Portugal & 1995 & Venezuela & 1999 \\
\hline
\end{tabular}


Table 2: Summary Statistics.

\begin{tabular}{|c|c|c|c|c|c|}
\hline & N. Obs & Mean & Std. Dev. & Min & Max \\
\hline \multicolumn{6}{|l|}{ FOREIGN AFFILIATES } \\
\hline Employment & 96276 & 748.319 & 2310.622 & \multicolumn{2}{|c|}{ (confidential) } \\
\hline $\ln ($ Employment $)$ & 96276 & 5.454 & 1.484 & \multicolumn{2}{|c|}{ (confidential) } \\
\hline Av. Annual Emp Growth (\%) & 96276 & 0.074 & 0.587 & \multicolumn{2}{|c|}{ (confidential) } \\
\hline BTT & 96276 & 0.801 & 0.399 & 0 & 1 \\
\hline Differentiated Input Share & 96276 & 0.547 & 0.202 & 0.169 & 0.947 \\
\hline Parent-Sibling BTTs ${ }^{a}$ & 96276 & 0.564 & 0.386 & 0 & 1 \\
\hline Affiliate-Sibling BTTs ${ }^{b}$ & 96276 & 0.096 & 0.159 & 0 & 1 \\
\hline $\ln \left(G D P_{u s}+G D P_{d}\right)$ & 96276 & 9.277 & 0.212 & 8.867 & 10.093 \\
\hline $\ln \left(G D P_{u s}-G D P_{d}\right)^{2}$ & 96276 & 18.092 & 0.491 & 14.841 & 18.933 \\
\hline $\ln ($ Skill Difference) & 96276 & 1.130 & 0.721 & 0 & 2.485 \\
\hline $\ln ($ Trade Cost $)$ & 96276 & 2.866 & 2.249 & 0 & 4.594 \\
\hline BIT & 96276 & 0.030 & 0.171 & 0 & 1 \\
\hline FTA & 96276 & 0.142 & 0.349 & 0 & 1 \\
\hline Exchange Rate & 96276 & 124.981 & 700.521 & $1.27 \mathrm{E}-09$ & 16105.13 \\
\hline \multicolumn{6}{|l|}{ US PARENT FIRMS } \\
\hline Foreign Affiliate Employment & 18747 & 3522.88 & 12801.78 & \multicolumn{2}{|c|}{ (confidential) } \\
\hline $\ln ($ Aff Emp) & 18747 & 6.355 & 1.899 & \multicolumn{2}{|c|}{ (confidential) } \\
\hline Av Annual Aff Emp Growth (\%) & 18747 & 10.313 & 0.678 & \multicolumn{2}{|c|}{ (confidential) } \\
\hline US Employment & 18747 & 8645.468 & 22063.59 & \multicolumn{2}{|c|}{ (confidential) } \\
\hline $\ln$ (US Employment) & 18747 & 7.755 & 1.686 & \multicolumn{2}{|c|}{ (confidential) } \\
\hline Number of Affiliates & 18747 & 4.688 & 7.150 & \multicolumn{2}{|c|}{ (confidential) } \\
\hline $\ln \left(G D P_{u s}+G D P_{d}^{c}\right.$ & 18747 & 9.292 & 0.191 & 8.905 & 10.093 \\
\hline $\ln \left(G D P_{u s}-G D P_{d}\right)^{2 c}$ & 18747 & 18.127 & 0.400 & 14.841 & 18.928 \\
\hline $\ln (\text { Skill Difference })^{c}$ & 18747 & 1.032 & 0.502 & 0 & 2.480 \\
\hline $\ln (\text { Trade Cost })^{c}$ & 18747 & 2.824 & 1.694 & 0 & 4.479 \\
\hline $\mathrm{BIT}^{c}$ & 18747 & 0.017 & 0.085 & 0 & 1 \\
\hline $\mathrm{FTA}^{c}$ & 18747 & 0.217 & 0.348 & 0 & 1 \\
\hline Exchange Rate $^{c}$ & 18747 & 65.839 & 225.884 & $1.14 \mathrm{E}-07$ & 6265.78 \\
\hline
\end{tabular}

${ }^{a}$ Weighted average share of total sibling employment covered by a BTT with the US, using $t-1$ affiliate employment shares as weights. ${ }^{b}$ Weighted average share of total sibling employment covered by a BTT with the affiliate's country, using $t-1$ affiliate employment shares as weights. ${ }^{c}$ Parent-level versions of affiliate country controls are aggregated from the country to the parent firm level using a weighted average in which the weights are lagged shares of total foreign employment of the firm in each country. 
Table 3: The Relationship between BTTs and Offshoring, Foreign Affiliate Level

\begin{tabular}{|c|c|c|c|c|c|c|}
\hline $\begin{array}{l}\text { Sample: } \\
\text { Depvar: }\end{array}$ & $\begin{array}{c}1 \\
\text { High dif } \\
\operatorname{lnm}_{a t}\end{array}$ & $\begin{array}{c}2 \\
\text { Low dif } \\
\ln _{a t}\end{array}$ & $\begin{array}{c}3 \\
\text { High dif } \\
\operatorname{lnm}_{a t}\end{array}$ & $\begin{array}{c}4 \\
\text { Low dif } \\
\ln m_{a t}\end{array}$ & $\begin{array}{c}\quad 5 \\
\text { High dif } \\
\operatorname{lnm}_{a t}\end{array}$ & $\begin{array}{c}6 \\
\text { Low dif } \\
\ln m_{a t}\end{array}$ \\
\hline btt (3 yrs post) & $\begin{array}{c}0.104^{* * *} \\
(0.031)\end{array}$ & $\begin{array}{l}-0.007 \\
(0.061)\end{array}$ & $\begin{array}{c}0.114^{* * *} \\
(0.036)\end{array}$ & $\begin{array}{l}-0.006 \\
(0.053)\end{array}$ & $\begin{array}{c}0.117 * * * \\
(0.037)\end{array}$ & $\begin{array}{l}-0.004 \\
(0.066)\end{array}$ \\
\hline$>3$ yrs post btt & $\begin{array}{c}0.228^{* * *} \\
(0.074)\end{array}$ & $\begin{array}{c}0.011 \\
(0.062)\end{array}$ & $\begin{array}{c}0.228^{* * *} \\
(0.085)\end{array}$ & $\begin{array}{c}0.003 \\
(0.067)\end{array}$ & $\begin{array}{c}0.232^{* * *} \\
(0.009)\end{array}$ & $\begin{array}{c}0.006 \\
(0.067)\end{array}$ \\
\hline$>3$ yrs pre btt & $\begin{array}{c}-0.086 \\
(0.064)\end{array}$ & $\begin{array}{l}-0.036 \\
(0.035)\end{array}$ & $\begin{array}{c}-0.066 \\
(0.061)\end{array}$ & $\begin{array}{l}-0.025 \\
(0.032)\end{array}$ & $\begin{array}{l}-0.067 \\
(0.013)\end{array}$ & $\begin{array}{l}-0.026 \\
(0.031)\end{array}$ \\
\hline $\ln \left(G D P_{u s}+G D P_{d}\right)$ & & & $\begin{array}{c}3.508^{* * *} \\
(0.785)\end{array}$ & $\begin{array}{c}1.366^{*} \\
0.798\end{array}$ & $\begin{array}{c}3.520^{* * *} \\
(0.778)\end{array}$ & $\begin{array}{l}1.370^{*} \\
(0.799)\end{array}$ \\
\hline $\ln \left(G D P_{u s}-G D P_{d}\right)^{2}$ & & & $\begin{array}{c}0.072 \\
(0.072)\end{array}$ & $\begin{array}{c}-0.127^{*} \\
(0.066)\end{array}$ & $\begin{array}{c}0.074 \\
(0.071)\end{array}$ & $\begin{array}{c}-0.126^{*} \\
(0.067)\end{array}$ \\
\hline $\ln$ (Skill Difference) & & & $\begin{array}{l}-0.055 \\
(0.049)\end{array}$ & $\begin{array}{c}0.020 \\
(0.042)\end{array}$ & $\begin{array}{l}-0.054 \\
(0.048)\end{array}$ & $\begin{array}{c}0.021 \\
(0.042)\end{array}$ \\
\hline $\ln$ (Trade Costs) & & & $\begin{array}{l}-0.015 \\
(0.011)\end{array}$ & $\begin{array}{l}-0.006 \\
(0.011)\end{array}$ & $\begin{array}{l}-0.015 \\
(0.011)\end{array}$ & $\begin{array}{l}-0.006 \\
(0.011)\end{array}$ \\
\hline $\mathrm{BIT}$ & & & $\begin{array}{l}-0.039 \\
(0.333)\end{array}$ & $\begin{array}{c}-0.080^{*} \\
(0.045)\end{array}$ & $\begin{array}{l}-0.041 \\
(0.333)\end{array}$ & $\begin{array}{c}-0.081^{*} \\
(0.045)\end{array}$ \\
\hline FTA & & & $\begin{array}{l}-0.071 \\
(0.096)\end{array}$ & $\begin{array}{l}-0.030 \\
(0.034)\end{array}$ & $\begin{array}{l}-0.073 \\
(0.096)\end{array}$ & $\begin{array}{l}-0.031 \\
(0.034)\end{array}$ \\
\hline Exchange Rate & & & $\begin{array}{c}-6.9 \mathrm{e}-05^{*} \\
3.6 \mathrm{e}-05^{*}\end{array}$ & $\begin{array}{l}-1.9 \mathrm{e}-05 \\
(1.8 \mathrm{e}-05)\end{array}$ & $\begin{array}{c}-6.8 \mathrm{e}-05^{*} \\
(3.6 \mathrm{e}-05)\end{array}$ & $\begin{array}{l}-1.9 \mathrm{e}-05 \\
(1.8 \mathrm{e}-05)\end{array}$ \\
\hline Parent-Sibling BTTs & & & & & $\begin{array}{c}0.018 \\
(0.009)\end{array}$ & $\begin{array}{c}0.004 \\
(0.014)\end{array}$ \\
\hline Affiliate-Sibling BTTs & & & & & $\begin{array}{l}-0.063 \\
(0.071)\end{array}$ & $\begin{array}{l}-0.056 \\
(0.050)\end{array}$ \\
\hline Affiliate FE & YES & YES & YES & YES & YES & YES \\
\hline Industry-Year FE & YES & YES & YES & YES & YES & YES \\
\hline $\mathrm{N}:$ & 37702 & 58574 & 37702 & 58574 & 37702 & 58574 \\
\hline R-sq & 0.003 & 0.001 & 0.010 & 0.005 & 0.011 & 0.005 \\
\hline F-Statistic & 11.022 & 0.014 & 9.850 & 0.010 & 9.734 & 0.011 \\
\hline
\end{tabular}

Notes: ${ }^{* * *}$ and ${ }^{* * *}$ indicate significance at the 10, 5 and 1 percent levels, respectively. Standard errors clustered by country are in parentheses. 
Table 4: The Relationship Between Offshoring and Domestic Employment at US MNEs

\begin{tabular}{lccccc}
\hline Model: & 1 & 2 & 3 & 4 & 5 \\
Specification: & OLS & IV & IV & IV & IV \\
Sample: & All & All & All & New Aff & Cont. Aff \\
Depvar: & $\ln s_{h t}$ & $\ln s_{h t}$ & $\operatorname{lns}_{h t}$ & $\ln s_{h t}$ & $\operatorname{lns}_{h t}$ \\
\hline $\ln M_{h t}$ & $0.464^{* * *}$ & $0.134^{* * *}$ & $0.138^{* * *}$ & $0.069^{* *}$ & $0.161^{* * *}$ \\
& $(0.005)$ & $(0.015)$ & $(0.016)$ & $(0.033)$ & $(0.017)$ \\
$\ln \left(G D P_{u s}+G D P_{d}\right)$ & 0.172 & & 0.120 & -2.352 & 0.373 \\
& $(0.628)$ & & $(0.591)$ & $(1.365)$ & $(0.686)$ \\
$\ln \left(G D P_{u s}-G D P_{d}\right)^{2}$ & 0.475 & & $0.177^{*}$ & 0.025 & 0.197 \\
& $(0.361)$ & & $(0.102)$ & $(0.203)$ & $(0.127)$ \\
$\ln ($ Skill Difference $)$ & $0.131^{*}$ & & 0.001 & 0.099 & -0.013 \\
& $(0.077)$ & & $(0.032)$ & $(0.080)$ & $(0.037)$ \\
$\ln ($ Trade Costs $)$ & 0.022 & & -0.010 & 0.028 & -0.015 \\
& $(0.029)$ & & $(0.011)$ & $(0.036)$ & $(0.011)$ \\
BIT & $0.102^{* * *}$ & & 0.089 & 0.384 & 0.049 \\
& $(0.033)$ & & $(0.145)$ & $(0.297)$ & $(0.158)$ \\
FTA & $0.110^{* * *}$ & & -0.065 & -0.091 & -0.054 \\
& $(0.009)$ & & $(0.041)$ & $(0.143)$ & $(0.042)$ \\
Exchange Rate & $1.5 \mathrm{e}-04$ & & $2.6 \mathrm{e}-05$ & $-2.4 \mathrm{e}-05$ & $6.6 \mathrm{e}-05$ \\
& $(1.1 \mathrm{e}-04)$ & & $(4.5 \mathrm{e}-05)$ & $(6.7 \mathrm{e}-05)$ & $(4.7 \mathrm{e}-05)$ \\
\hline Parent FE & YES & YES & YES & YES & YES \\
Year FE & YES & YES & YES & YES & YES \\
N: & 18747 & 18747 & 18747 & 3454 & 15293 \\
R-sq & 0.306 & 0.069 & 0.075 & 0.072 & 0.078 \\
First Stage F-Stat & - & 7160.54 & 6552.90 & 1100.91 & 5409.60 \\
Hausman p value & - & 0.008 & 0.014 & 0.002 & 0.006 \\
\hline
\end{tabular}

Notes: ${ }^{*},{ }^{* *}$ and ${ }^{* * *}$ indicate significance at the 10, 5 and 1 percent levels, respectively. Standard errors clustered by parent firm and year are in parentheses. 
Table 5: Second Stage: Industry and MSA Level

\begin{tabular}{lccc}
\hline & 1 & 2 & 3 \\
Specification: & OLS & IV & IV \\
Depvar: & $\ln L_{i t}$ & $\ln L_{i t}$ & $\ln L_{m t}$ \\
\hline $\ln M_{i t}$ & $0.481^{* * *}$ & $0.048^{* *}$ & \\
& $(0.082)$ & $(0.022)$ & \\
$\ln M_{m t}$ & & & $0.095^{* *}$ \\
& & & $(0.045)$ \\
\hline Industry FE & YES & YES & - \\
MSA FE & - & - & YES \\
Year FE & YES & YES & YES \\
N: & 1198 & 1198 & 6384 \\
R-sq & 0.352 & 0.624 & 0.720 \\
First Stage F-Stat & - & 535.46 & 1188.18 \\
Hausman p value & - & 0.026 & 0.031 \\
\hline
\end{tabular}

Notes: ${ }^{* * *}$ and ${ }^{* * *}$ indicate significance at the 10, 5 and 1 percent levels, respectively. Standard errors clustered by industry or MSA and year are in parentheses. 


\section{Appendix}

\section{A First Stage Results}

Table A-1: First Stage: Parent Level

\begin{tabular}{lcccc}
\hline Model: & 1 & 2 & 3 & 4 \\
Sample: & All & All & New Aff & Cont. Aff \\
Depvar: & $\ln M_{h t}$ & $\ln M_{h t}$ & $\ln M_{h t}$ & $\ln M_{h t}$ \\
\hline$\widehat{\ln M_{h t}}$ & $0.959^{* * *}$ & $0.967^{* * *}$ & $0.958^{* * *}$ & $0.967^{* * *}$ \\
& $(0.011)$ & $(0.012)$ & $(0.029)$ & $(0.013)$ \\
$\ln \left(G D P_{u s}+G D P_{d}\right)$ & & 0.051 & -0.189 & 0.134 \\
& & $(0.403)$ & $(0.797)$ & $(0.485)$ \\
$\ln \left(G D P_{u s}-G D P_{d}\right)^{2}$ & & 0.029 & -0.024 & 0.079 \\
& & $(0.070)$ & $(0.141)$ & $(0.086)$ \\
$\ln ($ Skill Difference $)$ & & $0.078^{* *}$ & $0.195^{* * *}$ & $0.051^{*}$ \\
& & $(0.030)$ & $(0.067)$ & $(0.030)$ \\
$\ln ($ Trade Costs $)$ & & -0.012 & -0.012 & -0.015 \\
& & $(0.011)$ & $(0.034)$ & $(0.011)$ \\
BIT & & -0.174 & -0.285 & -0.186 \\
& & $(0.119)$ & $(0.333)$ & $(0.125)$ \\
FTA & & 0.059 & 0.087 & 0.058 \\
& & $(0.043)$ & $(0.100)$ & $(0.044)$ \\
Exchange Rate & & $2.2 \mathrm{e}-07$ & $-7.9 \mathrm{e}-06$ & $-5.7 \mathrm{e}-05$ \\
& & $(2.7 \mathrm{e}-05)$ & $(3.9 \mathrm{e}-05)$ & $(4.2 \mathrm{e}-05)$ \\
\hline Parent FE & YES & YES & YES & YES \\
Year FE & YES & YES & YES & YES \\
N: & 18847 & 18847 & 3454 & 15293 \\
R-sq & 0.728 & 0.726 & 0.785 & 0.800 \\
F-Statistic & 7160.54 & 6552.90 & 1100.91 & 5409.60 \\
\hline
\end{tabular}

Notes: ${ }^{*},{ }^{* *}$ and ${ }^{* * *}$ indicate significance at the 10, 5 and 1 percent levels, respectively. Standard errors clustered by parent and year are in parentheses. 
Table A-2: First Stage: Industry and MSA Level

\begin{tabular}{lcc}
\hline & 1 & 2 \\
Depvar: & $\ln M_{i t}$ & $\ln M_{m t}$ \\
\hline$\widehat{\ln M_{i t}}$ & $\begin{array}{c}0.809^{* * *} \\
(0.035)\end{array}$ & \\
& & \\
$\widehat{l n M_{m t}}$ & & $0.815^{* * *}$ \\
& & $(0.024)$ \\
\hline Industry FE & YES & - \\
MSA FE & - & YES \\
Year FE & YES & YES \\
N: & 1198 & 6384 \\
R-sq & 0.851 & 0.911 \\
F-Statistic & 535.46 & 1188.18 \\
\hline
\end{tabular}

Notes: ${ }^{*},{ }^{* *}$ and $* * *$ indicate significance at the 10, 5 and 1 percent levels, respectively. Standard errors clustered by industry or MSA and year are in parentheses. 